DOI: https://doi.org/10.12797/Politeja.15.2018.54.02

Józef M. FISZER

Polska Akademia Nauk

fiszer@isppan.waw.pl

\title{
CZY BREXIT PRZYSPIESZY REWIZJE TRAKTATU LIZBOŃSKIEGO I URATUJE UNIĘ EUROPEJSKĄ?
}

ABSTRACT Does Brexit previously revise the Lisbon Treaty and rescue European Union? There is no doubt that Brexit is an unprecedented event in the history of European integration and in the history of the European Union (EU). It will certainly be a turning point not only in the history of the EU, but also in Europe, and will have an impact on their place and role in the new, emerging international order. Today it is very difficult to present an accurate diagnosis, and even more, difficult to predict the future of the EU, Europe, and the whole world after Brexit.

The purpose of this article is an attempt to answer a few questions, especially on the question contained in its title and to present the opportunities and threats for the European Union after Brexit. In addition, the author is trying to answer the question whether, at all, today, nine years after the entry into force of the Treaty of Lisbon, its revision is needed? Does the EU really need a new treaty? Currently, opinions on this subject are divided among researchers and experts. Many also are afraid that Brexit will be the beginning of the end of the Union, that it will lead to the so-called diversified integration and then to its disintegration. Others believe that the Brexit may become an accelerator of the European Union's modernization process, which will, however, require the adoption of a new revision treaty.

Keywords: Brexit, European Union, Treaty of Lisbon

Słowa kluczowe: Brexit, Unia Europejska, traktat z Lizbony 


\section{WPROWADZENIE}

Nie ulega wątpliwości, że Brexit jest bezprecedensowym wydarzeniem w dziejach europejskiej integracji i w historii Unii Europejskiej. Stanowić będzie cezurę w historii nie tylko UE, lecz także Europy i nie pozostanie bez wpływu na ich miejsce i rolę w nowym ładzie międzynarodowym. Do tej pory mieliśmy bowiem do czynienia jedynie z kolejnymi akcesjami do Wspólnot Europejskich i Unii Europejskiej, czyli z procesem ich poszerzania i pogłębiania, w którego efekcie UE liczy obecnie 28 członków. Natomiast do czasu wejścia w życie traktatu z Lizbony w dniu 1 grudnia 2009 r., który nadał UE osobowość prawną, w prawie unijnym nie było nawet wzmianki o możliwości jej opuszczenia. Traktat lizboński stanowi, że każde państwo członkowskie może podjąć decyzję o wystąpieniu z Unii zgodnie ze swoimi wymogami konstytucyjnymi. Jeżeli dane państwo podejmie taką decyzję, notyfikuje swój zamiar Radzie Europejskiej, która wydaje stosowne wytyczne w tej sprawie. W dniu 29 marca 2017 r. Wielka Brytania podjęła taką decyzję i uruchomiony został art. 50 traktatu o UE, który przewiduje maksymalnie dwa lata na negocjacje. Następnie Rada Unii Europejskiej, stanowiąc większością kwalifikowaną po uzyskaniu zgody Parlamentu Europejskiego, zawiera z takim państwem umowę określającą warunki wystąpienia z UE (art. 50 ust. 1-2 TUE)1.

Podjęta przez Brytyjczyków w referendum 23 czerwca 2016 r. decyzja o wyjściu Wielkiej Brytanii z UE wywołała niekończące się dyskusje i spory wśród polityków tego państwa oraz w Unii i państwach członkowskich, a także wśród ekspertów i badaczy na całym świecie. Brytyjczycy jako pierwsi skorzystali z art. 50 traktatu lizbońskiego i opowiedzieli się za wystąpieniem z UE. Brexit ma wielu zwolenników i przeciwników wśród Brytyjczyków i Europejczyków. U jednych wywołuje radość, u innych złość i strach. Przetrwanie wszystkich implikacji referendum w Wielkiej Brytanii z pewnością długo jeszcze będzie absorbować ten kraj, Europę i cały świat. Konsekwencje Brexitu będą zależały od reakcji Unii Europejskiej na wycofanie się z niej Wielkiej Brytanii. Notabene, relacje między Londynem i Brukselą nigdy nie były łatwe, zarówno przed akcesją Zjednoczonego Królestwa do Wspólnot Europejskich w 1973 r., jak i po niej. Wielka Brytania ze względu na swoje położenie geopolityczne oraz potencjały, zwłaszcza gospodarczy i militarny, zawsze odgrywała ważną rolę w dziejach Europy i świata. Obok Niemiec i Francji była najważniejszym uczestnikiem powstałego po II wojnie światowej systemu transatlantyckiego oraz miała istotne znaczenie w procesie integracji Europy ${ }^{2}$.

Traktat z Lizbony, zmieniajacy Traktat o Unii Europejskiej i Traktat ustanawiajacy Wspólnotę Europejska, podpisany w Lizbonie 13 grudnia 2007 r. (teksty skonsolidowane), Dz.U. UE 2010, C 83. Por. także: J.J. Węc, Traktat lizboński. Polityczne aspekty reformy ustrojowej Unii Europejskiej w latach 2007-2009, Kraków 2011, s. 137; Podstawy prawne Unii Europejskiej. Traktat z Lizbony, Traktat o Unii Europejskiej, Traktat ofunkcjonowaniu Unii Europejskiej wraz z protokotami i deklaracjami, Karta Praw Podstawowych, wprow., wybór i oprac. J. Barcz, Warszawa 2010; M. Czarnecki, BREXIT niezgody, „Gazeta Wyborcza" 2017, 5 V, s. 11.

2 K. Łastawski, Od idei do integracji europejskiej, Warszawa 2003; J. Smith, Europa und das Vereinigte 
Można postawić tezę, że Brexit będzie miał daleko idące konsekwencje - zarówno pozytywne, jak i negatywne - dla UE, a tym samym dla całej Europy oraz jej przyszłości. Uważam, że Brexit poważnie osłabi UE, która po wyjściu Wielkiej Brytanii utraci sporo ze swego potencjału gospodarczego, finansowego, naukowo-technicznego, politycznego, a także militarnego. W efekcie cały system euroatlantycki, którego ważnym filarem jest Unia Europejska, ulegnie osłabieniu. Słaby system euroatlantycki nie będzie też efektywnym systemem bezpieczeństwa dla Europy i świata. Brexit osłabi również rolę UE w budowie nowego ładu globalnego, będącego wciąż in statu nascendi. To zaś wzmocni pozycję państw należących do tzw. grupy BRIC, zwłaszcza Chin i Rosji. Nowy ład globalny bez UE lub ze słabą Unią będzie ładem bipolarnym, na czele z Chinami i Stanami Zjednoczonymi, lub tripolarnym, tzn. z dominującą rolą Chin, Stanów Zjednoczonych i Rosji. Utworzenie takiego systemu międzynarodowego od dawna proponuje Stanom Zjednoczonym i Chinom prezydent Rosji Władimir Putin. W takim ładzie globalnym wzrośnie rola Rosji, zaś UE stanie się jego peryferiami. W ostatnich latach kraj ten pokazał, że w dążeniu do osiągnięcia swoich interesów jest gotów użyć siły, że może ją wykorzystać dla zmiany granic w najbliższym środowisku i prowadzić politykę na granicy prowokacji poważnego konfliktu międzynarodowego. Putin i rosyjskie elity oraz media dopatrują się wszędzie wrogów i twierdzą, że szkodzą oni interesom narodowym tego wielkiego mocarstwa. Prezydentowi udało się odbudować mocarstwowy wizerunek Rosji i przekonać doń nie tylko Rosjan, lecz także Zachód. $\mathrm{Z}$ jej aspiracjami i determinacją w obronie własnych interesów liczą się dziś największe potęgi świata ${ }^{3}$.

Osłabiona Brexitem, zmarginalizowana na arenie międzynarodowej UE będzie dryfowała, ulegając dalszej erozji, i ostatecznie rozpadnie się. Jeśli do tego dojdzie, będzie to wielki sukces Putina i polityki zagranicznej Rosji, która od wielu lat właśnie do tego dąży. Rosja szczególnie zaś neguje politykę wschodnią Unii Europejskiej, a zwłaszcza cele Partnerstwa Wschodniego. Zarzuca Unii, że prowadzi politykę antyrosyjską ${ }^{4}$ Zarazem będzie to wielki dramat dla Europy, zwłaszcza dla państw Europy Środkowo-Wschodniej, w tym także dla Polski, która bez Unii Europejskiej ponownie znajdzie się w strefie wpływów Rosjis.

Polska może też ponownie znaleźć się między potężnymi Niemcami i Rosją, gdyż wszystko wskazuje na to, że po Brexicie rola Niemiec w UE i w ogóle w Europie gwałtownie wzrośnie (a jeszcze bardziej wzrosłaby po rozpadzie Unii). Brexit doprowadzi bowiem do zachwiania politycznej równowagi, jaką w pewnym stopniu zapewniała

Königreich. Kleine Geschichte der Beziehungen seit 1945, „Aus Politik und Zeitgeschichte” 2016, nr 49-50, s. 11-16.

S. Bieleń, Wizerunki międzynarodowe Rosji, „Polityka Polska” 2016, nr 5-6, s. 46-47.

B. Piskorska, Soft power w polityce UE wobec państw Partnerstwa Wschodniego, Lublin 2017.

J.M. Fiszer, Zadania i cele polityki zagranicznej Wtadimira Putina, „Myśl Ekonomiczna i Polityczna” 2016, nr 1, s. 167-201; J. Afanasjew, Grożna Rosja, przeł. M. Kotowska, Warszawa 2004; Polityka zagraniczna Rosji, red. S. Bieleń, M. Raś, Warszawa 2008; A. Bryc, Europejska Polityka Sasiedztwa w perspektywie rosyjskiej, [w:] Europejska Polityka Sąsiedztwa Unii Europejskiej. Geneza, doświadczenia, perspektywy, red. J.M. Fiszer, Warszawa 2012, s. 128-139. 
Wielka Brytania dla niemiecko-francuskiego tandemu; obecne problemy Francji pozwalają przypuszczać, że to Niemcy staną się niekwestionowanym liderem UE. Nie musi to jednak oznaczać, że Niemcy od razu staną się zagrożeniem dla UE i bezpieczeństwa Europy. Wprost przeciwnie. Jak pisze na łamach dziennika „Handelsblatt” prof. Marcel Fratzscher, dyrektor renomowanego Niemieckiego Instytutu Badań Gospodarczych (DIW):

Przy wszystkich troskach i ryzykach decyzja w sprawie Brexitu jest szansa, którą Europa powinna odważnie wykorzystać. Stoimy na rozdrożu, gdzie okaże się, czy kontynent na nowo rozpadnie się w któcace się państwa narodowe, czy powstanie Europa silniejsza $i$ bardziej socjalna. Niemcy jako silny największy kraj, gospodarczo silny i politycznie stabilny, mają tu szczególna odpowiedzialność. Niemiecki rząd powinien wystapić do swoich partnerów z konkretnym planem. To wymaga odwagi i niesie ze soba ryzyka polityczne, ale jest jedyna szansa, by zapewnić Europie i Niemcom dobrobyt i perspektywy na przysztość. Apel tego wpływowego ekonomisty nie pozostał bez echa wśród niemieckich polityków, o czym świadczy ogłoszony z inicjatywy ówczesnego ministra spraw zagranicznych, dziś prezydenta RFN Franka-Waltera Steinmeiera i francuskiego polityka Jeana-Marca Ayraulta manifest pt. Silna Europa w niepewnym świecie. W tym dziesięciostronicowym dokumencie ministrowie podkreślili, że współpraca Niemiec i Francji znów będzie miała kluczowe znaczenie dla przyszłości Europy. Wzywali, by po Brexicie UE stała się unia bezpieczensstwa ze wspólną polityką obronną. Zaproponowali również zintegrowaną europejską politykę azylową i migracyjną, która przewidywałaby wią̇ące mechanizmy przy podziale obciązeń między państwami cztonkowskimi. Dodatkowo przedstawili cały pakiet propozycji dotyczących kwestii społeczno-gospodarczych, szczególnie w strefie euro. Zaproponowali m.in.: ujednolicenie systemów podatkowych dla przedsiębiorstw, zwiększenie europejskich funduszy na strategiczne inwestycje w energię, gospodarkę cyfrową, badania i innowacje, wprowadzenie minimalnych standardów socjalnych?

Wcześniej z podobną inicjatywą wyszli partyjni koledzy Steinmeiera: ówczesny szef SPD i wicekanclerz Niemiec Sigmar Gabriel oraz ówczesny przewodniczący Parlamentu Europejskiego Martin Schulz. Już w dniu referendum w Wielkiej Brytanii wydali oni manifest wzywajacy do nowego aktu zatożycielskiego Europy. Przedstawili w nim dziesięciopunktowy plan, który w dużej mierze pokrywa się z propozycjami Steinmeiera i Ayraulta, np. w kwestiach wspólnej polityki migracyjnej, bezpieczeństwa Europy czy większych wydatków na inwestycje z budżetu Unii Europejskiej ${ }^{8}$.

RFN i Unia Europejska polegały dotychczas w dziedzinie bezpieczeństwa na Stanach Zjednoczonych, ale nowy prezydent Donald Trump na razie nie angażuje się w sojusz transatlantycki tak mocno, jak jego poprzednicy, dla których Europa była naturalnym sojusznikiem Ameryki. Jego retoryka wobec Niemiec, NATO i Rosji sugeruje, że

6 A. Godlewski, Co Niemcy straca, a co zyskają na Brexicie, Obserwatorfinansowy.pl, 5 VII 2016, [online] https://www.obserwatorfinansowy.pl/tematyka/makroekonomia/co-niemcy-straca-a-co-zyskajana-brexicie/.

Tamże, s. 3.

Tamże. 
utrzymanie obecnego poziomu zaangażowania Stanów Zjednoczonych w Europie nie jest pewne. Co więcej, dzieje się to w kontekście słabnącej już od kilku lat obecności USA na całym globie. Dzisiaj Waszyngton ma mniej żołnierzy stacjonujących za granicą niż kiedykolwiek od 1957 r., kiedy zaczęto takie dane gromadzić'

Nasuwa się więc pytanie: czy staniemy się świadkami powstania „postamerykańskiej Europy”, w której bardziej intensywna europejska integracja obronna zastąpi amerykańskie gwarancje bezpieczeństwa, a państwa europejskie będą zajmowały bardziej zdecydowane stanowiska wobec niepopularnych działań Stanów Zjednoczonych? Słowa kanclerz Angeli Merkel, wygłoszone podczas spotkania wyborczego pod koniec maja 2017 r. w Bawarii, wzywającej do tego, by Europa wzięta swój los we własne ręce, spotęgowały w Niemczech ożywioną dyskusję na ten temat.

Taka postawa nie jest jednak w Niemczech nowa. Pokazuje ona przemianę polityczną, która rozpoczęła się po referendum w sprawie Brexitu w Wielkiej Brytanii i nabrała tempa po wyborze Trumpa na prezydenta USA. Z wypowiedzi niemieckich polityków dziś wyraźnie wynika, że ambicje Niemców wobec Unii Europejskiej rosną, pomimo licznych wewnętrznych i zewnętrznych zagrożeń, którym musi ona stawić czoło. Unia Chrześcijańsko-Demokratyczna (CDU) pod przywództwem Merkel oraz Socjaldemokratyczna Partia Niemiec (SPD) kierowana dziś przez Schulza, podobnie jak prawie wszystkie inne niemieckie partie polityczne, bardzo dbają o to, by Niemcy utrzymały swoje zaangażowanie w UE, również po to, by wykorzystać ją do zwielokrotnienia swoich wpływów. To zaangażowanie nie jest zagrożone przez eurosceptyczne nastroje wśród niemieckiej opinii publicznej, na których antyunijna partia Alternatywa dla Niemiec (AfD) stara się budować swoje poparcie. W raporcie pt. Niemcy gtosują: europejskie dylematy w wyborach do Bundestagu Almut Möller, dyrektorka berlińskiego biura European Council on Foreign Relations (ECFR), podkreśla, że $w$ zderzeniu z Brexitem i Trumpem niemieccy politycy wykazuja się niespotykana wcześniejpewnościa, że moga „wzią́ byka za rogi” i dążyć do powołania nowych koalicji wewnątrz Unii Europejskiej ${ }^{10}$. Socjaldemokrata Sigmar Gabriel, minister spraw zagranicznych Niemiec, w programie dla Europy mówił, że Niemcy powinny chłodniej traktować partnerstwo z USA, bo zapewne przez dłuższy czas będą z Waszyngtonem skłócone, i łagodzić sankcje wobec Rosji. Szef SPD Martin Schulz wzywał z kolei do reformy UE i takiej polityki, która na pierwszym miejscu postawi Europę, na drugim kraj, a dopiero na trzecim - interes partyjny. Jego zdaniem Niemcy powinny podchwycić inicjatywę prezydenta Francji Emmanuela Macrona i nawet ją pogłębić, czyli dążyć do przekształcenia UE w Stany Zjednoczone Europy ${ }^{11}$. Dziś to mało prawdopodobne, ale prawdą jest, że Unia Europejska potrzebuje daleko idących reform, których bez aktywnego działania Niemiec nie da się przeprowadzić. Unia jest nadal w kryzysie, zagubiona w scholastycznych

9 J. Shapiro, D. Pardijs, The Transatlantic Meaning of Donald Trump: A US-EU Power Audit, European Council on Foreign Relations, 25 IX 2017, [online] http://www.ecfr.eu/publications/summary/ the_transatlantic_meaning_of_donald_trump_a_us_eu_power_audit7229.

10 A. Möller, A. Aydintasbas, S. Dullien, K. Liik, Germany Votes: European Dilemmas in the Federal Election, European Council on Foreign Relations, Policy Brief, V 2017.

11 A. Krzemiński, Do tanga trzeba trojga, „Polityka” 2018, nr 3, s. 44-45. 
rozważaniach, lękach i braku metody do zrealizowania tego, co pozostaje zbyt często tylko gadaniem - sympatycznym, ale pustym. Pokazał to także zakończony 19 stycznia 2018 r. szczyt państw i rządów UE w Brukseli.

Mimo ostrego wystąpienia Merkel i aktywności wielu polityków niemieckich większość państw członkowskich UE woli stary układ z Waszyngtonem od niezależności, która pociąga za sobą nieznane zagrożenia. Panuje atmosfera wyczekiwania, można też dostrzec wiarę, że „szalony Trump” albo zostanie pozbawiony funkcji prezydenta USA, albo zacznie wreszcie słuchać swoich doradców, Kongresu i amerykańskiego społeczeństwa obywatelskiego. Dzięki temu ostatecznie przywrócone zostaną ,normalne” relacje w polityce Stanów Zjednoczonych i stosunkach transatlantyckich. Takie myślenie widoczne jest także wśród większości niemieckiego społeczeństwa, dla którego najważniejszym partnerem dla Stanów Zjednoczonych jest Europa (i Niemcy). Z kolei w Europie powszechna jest głęboka nieufność wobec niemieckiego przywództwa. Aby wyjść z tej patowej sytuacji, Berlin musiałby sformować koalicję państw członkowskich - począwszy od Francji Macrona - które widzą w niemieckim przywództwie korzyść dla siebie. Musiałby także znaleźć do sprawowania tego przywództwa mechanizm, który przekona partnerów, że Niemcy nie będą nadużywać swojej pozycji. Teoretycznie rzecz biorąc, Europa, której przewodzą Niemcy, jest możliwa, ale w praktyce nie jest to prawdopodobne, bo Europejczycy - jak pokazują badania - boją się takiej wizji, a Niemcy tak naprawdę jej nie chcą ${ }^{12}$.

Dziś bardzo trudno jest opracować trafną diagnozę, a jeszcze trudniej przedstawić obiektywną prognozę co do przyszłości UE, Europy i całego świata po Brexicie. Tym bardziej że sytuacja na świecie jest dynamiczna i nieprzewidywalna. Porozumienia i traktaty międzynarodowe oraz kardynalne zasady prawa międzynarodowego nie są respektowane. Przykładem może być memorandum budapeszteńskie z 1994 r., podpisane przez wszystkich członków Rady Bezpieczeństwa ONZ, które miało gwarantować integralność terytorialną i bezpieczeństwo Ukrainy, która wyrzekła się broni atomowej a tymczasem 20 lat później utraciła ona $\mathrm{Krym}^{13}$.

Świat po zimnej wojnie radykalnie się zmienia. Najwyraźniej zakończyła się „jednobiegunowa chwila" absolutnego triumfu Stanów Zjednoczonych Ameryki po upadku ładu zimnowojennego. Już na początku XXI w. środek ciężkości świata wyraźnie przesunął się w kierunku Azji. Wynikało to w pierwszej kolejności z wejścia licznych gospodarek azjatyckich w fazę szybkiego wzrostu oraz równoległego szybkiego zwiększenia się populacji tego kontynentu, przy jednoczesnym niżu demograficznym i starzeniu się Europy oraz Ameryki. W wymiarze gospodarczym i finansowym światowy porządek ponownie zamienił się $\mathrm{w}$ wielobiegunowy, czego dowodami są przemiana G-7 w G-20 oraz wyłonienie się ugrupowania państw BRICS (Brazylia, Rosja, Indie, Chiny, RPA). Następuje wyraźne przesuniecie ośrodka siły (gospodarczej, a w ślad za tym politycznej) z Atlantyku na Pacyfik, co niektórych badaczy i ekspertów prowadzi do formułowania tezy, że następuje dziś (relatywny) zmierzch świata atlantyckiego,

12 J. Shapiro, D. Pardijs, The Transatlantic Meaning...

13 D. Warszawski, Nadchodzi czas Trumpów, „Gazeta Wyborcza”, 30 XII 2017-1 I 2018, s. 10. 
jak też dotychczasowego porządku, zdominowanego przez Zachód i wartości liberalne. W ramach tych zmian zachodzi wiele innych procesów, często o dużym znaczeniu geopolitycznym i geoekonomicznym. Trudno więc przewidzieć, czy wiek XXI będzie nadal wiekiem Ameryki i Europy, czy może Azji na czele z Indiami i Chinami. Nie wiemy, czy prezydent Trump swoją polityką doprowadzi do rozkładu systemu transatlantyckiego, czy też go wzmocni. Czy zrezygnuje z podpisania umowy o wolnym handlu między Unią Europejską a Stanami Zjednoczonymi (Trans-Atlanic Free Trade Agrement, TAFTA) i powołania do życia Transatlantyckiego Partnerstwa Handlowego i Inwestycyjnego (Trans-Atlantic Trade and Investment Partnership, TTIP)? Początkowo Trump bardzo ostro stawiał się też Chinom, ale potem „kokietowal” je w nadziei na pomoc w Korei. Ostatecznie jednak zrezygnował z zamiaru wojny w Korei Północnej, z czego Chiny mogły wywnioskować, że Stany Zjednoczone są jednak papierowym tygrysem.

Dziś trudno jest prognozować, jaki będzie XXI w., gdyż świat, a zwłaszcza Europa, Ameryka, Unia Europejska i NATO, a więc najważniejsze komponenty dotychczasowego systemu międzynarodowego, wciąż borykają się z wieloma problemami społecznymi, politycznymi i ekonomicznymi. Świat długo pozostanie niestabilny, nawet jeśli uda się opanować kryzysy w UE (finansowy, euro, terrorystyczny, migracyjny, przywództwa) i uregulować trwające na świecie konflikty międzynarodowe oraz powstrzymać imperialne zapędy Chin i Rosji. Już kryzys finansowo-gospodarczy zapoczątkowany w 2008 r. ujawnił wyczerpywanie się zasad i form, na których opiera się dotychczasowy lad polityczno-społeczny i ekonomiczny Zachodu, determinowanych ustrojem liberalno-demokratycznym, a zwłaszcza jego obecną postacią, tj. neoliberalizmem. Niewątpliwie stał się on zapowiedzią nadchodzących zmian w układzie geopolitycznym i geoekonomicznym, warunkowanych do tej pory w głównej mierze przez hegemoniczną pozycję Stanów Zjednoczonych na świecie.

Tymczasem lata 2008-2017 pokazują wyraźnie, że słabnie rola Wspólnoty Atlantyckiej na arenie międzynarodowej, gdyż Stany Zjednoczone, Unia Europejska i NATO wciąż nie mogą osiągnąć konsensu co do dalszej współpracy i walki o pokój na świecie. Drogi Europy i USA mocno się rozeszły, ich wzajemne więzi i współpraca nie są już tak mocne jak w latach zimnej wojny. Okazuje się też, że Wspólnota Atlantycka była kompletnie nieprzygotowana na upadek ładu bipolarnego i rozpad sowieckiego imperium. Zaskoczyła ją arabska wiosna, podobnie jak wydarzenia na Ukrainie i w Syrii czy Państwo Islamskie, które zagraża bezpieczeństwu świata. Na początku lat 90. XX w. założono bowiem błędnie, że neoliberalny świat rozwijający się pod kontrolą Stanów Zjednoczonych, świat wolnego rynku i demokracji przyniesie rozwiązania, które doprowadzą do powstania nowego wspaniałego świata wolności, demokracji, pokoju i dobrobytu, ukształtowanego na obraz i podobieństwo Pax Americana. Tak się jednak nie stało. Podczas jednego z ostatnich wystąpień prezydent Barack Obama stwierdził: Niemal w każdym kraju na planecie Ameryka jest dziś postrzegana jako silniejsza niż osiem lat temu ${ }^{14}$. Zapewne sam nie wierzy w te słowa, gdyż jego prezydentura to kolejna deka-

14 M. Jarkowiec, Do zobaczenia, panie prezydencie, „Gazeta Wyborcza” 2017, 14-15 I, s. 13. 
da postępującego od zamachów z 11 września 2001 r. schyłku amerykańskiej potęgi ${ }^{15}$. W dużym stopniu decydują o tym globalne procesy, na które Stany Zjednoczone mają coraz mniejszy wpływ.

Chiny na przykład już nie ukrywają swoich celów i możliwości. W ostatnich latach odchodzą od dewizy Deng Xiaopinga, by „nie wychodzić przed szereg”; wykazują coraz większe ambicje globalne i stopniowo, ale znacząco zwiększają swoją obecność za granicą. Chiny aktywnie promują strategiczne inwestycje w Azji Środkowej, Europie i Afryce, a także działają coraz bardziej asertywnie we własnym sąsiedztwie, eskalując napięcia wokół sporów terytorialnych. Chcą Tajwanu, dominacji nad Azją Środkową i kontroli szlaków handlowych. Temu też ma służyć Nowy Jedwabny Szlak, który w przeciwieństwie do historycznej drogi łączącej Chiny z Europą i Bliskim Wschodem - tak naprawdę jest ideą, a nie szlakiem. Chodzi bowiem o globalizację roli gospodarczej i politycznej Chin, głównie przez inwestycje. A konkretniej - wyparcie z Azji Południowo-Wschodniej, Azji postradzieckiej oraz Turcji i Iranu rosyjskich i amerykańskich wpływów. Inwestycje mają być wzbogacające dla obu stron, przez co w niektórych kręgach Nowy Jedwabny Szlak nazywany jest chinskim planem Marshalla ${ }^{16}$. Jak podkreśla prof. Zbigniew Brzeziński: kto ma kontrolę nad Azją Środkową, ten kontroluje Europę i Azję. Ponadto przywódca Chin Xi Jinping wykorzystał lukę stworzoną przez Stany Zjednoczone w 2016 r., stawiając się w roli orędownika globalizacji i wolnego handlu. Jednak w wielu obszarach chińska wizja globalnego ładu jest zasadniczo odmienna od tej, której hołdują zwolennicy liberalnego porządku międzynarodowego, tacy jak UE i Japonia. Otwartość Europy przyciągnęła wiele chińskich inwestycji oraz pozwoliła na zakup i transfer europejskich technologii do Chin, podczas gdy Pekin jest zamknięty na współpracę polityczną i w zakresie bezpieczeństwa. Aby przywrócić równowagę w tych stosunkach i obronić własne interesy, Europejczycy muszą jak najszybciej przyjąć bardziej realistyczne stanowisko.

Pekin odmówił także uznania, że Chiny nie są już rozwijającą się gospodarką. Autorytarna modernizacja pod przewodnictwem Xi Jinpinga pozostawia niewiele miejsca na jakąkolwiek konwergencję z Europą. Duża część ambitnego programu UE-Chiny 2020 pozostaje niezrealizowana ${ }^{17}$. Nawet w kwestii zmian klimatycznych, która jest oczywistym polem do wspólnych działań, Chiny w 2017 r. odrzuciły wspólną deklarację z Europą. Współpraca międzynarodowa, np. w zakresie misji pokojowych ONZ, ma charakter bardziej paralelny niż kooperatywny. Dlatego też UE powinna się dziś zastanowić: jak można zareagować na nowe ambicje Chin i czy istnieje sposób na

15 L. Pastusiak, Prezydent dobrych intencji. Polityka zagraniczna Baracka Obamy, Warszawa 2015.

16 Szerzej na ten temat zob. E. Bryła, Czy mamy szanse na chiński węzet?, „Gazeta Wyborcza” 2017, 15 IX, s. 10; F. Godement, Czego chca Chiny?, przeł. K. Sarek, Warszawa 2016, s. 243-249; E. Haliżak, Międzynarodowa strategia geoekonomiczna Chin - perspektywa neoliberalnego instytucjonalizmu i kulturowo-cywilizacyjnej tradycji, „Myśl Ekonomiczna i Polityczna” 2017, nr 2, s. 72-101; Xu Jian, Wspólnie budując Jedwabny Szlak XXI wieku promujemy i zacieśniamy przyjaźn, [w:] Chiny i świat zewnętrzny, red. J. Marszałek-Kawa, Toruń 2016, s. 149-154.

17 EU-China 2020 Strategic Agenda for Cooperation, European External Action Service, [online] http:// eeas.europa.eu/archives/docs/china/docs/eu-china_2020_strategic_agenda_en.pdf, 13 III 2018. 
konstruktywną współpracę z Państwem Środka? Przywódcy ChRL chcą bowiem, aby spełnił się „chiński sen”. Dążą do odbudowy Wielkich Chin i ma to zostać osiągnięte do 1 października 2049 r., tj. na stulecie ChRL. Czy wówczas Chiny zastąpią Stany Zjednoczone jako wielostronny podmiot w stosunkach międzynarodowych ${ }^{18}$

Swoich imperialnych celów i aspiracji do roli supermocarstwa w multipolarnym świecie nie ukrywają również Indie ${ }^{19}$ i Rosja pod rządami Putina, który już w 2007 r. podczas konferencji bezpieczeństwa w Monachium mówił o końcu świata ,jednobiegunowego", mając na myśli dominację Stanów Zjednoczonych. Rosja prowadzi coraz bardziej agresywną politykę zagraniczną, która zagraża Europie i światu. Putin już dawno postawił sobie konkretne cele na arenie międzynarodowej i sukcesywnie je realizuje od 2000 r. Jego głównymi zadaniami są rozbicie systemu euroatlantyckiego oraz odbudowa silnej Rosji i umocnienie jej pozycji na arenie międzynarodowej jako supermocarstwa, dysponującego adekwatnymi do tego statusu potencjałami, zwłaszcza gospodarczym i militarnym. Cele i zadania, jakie Putin postawił przed polityką zagraniczną i militarną Rosji, są niebezpieczne dla Unii Europejskiej, Europy i świata, gdyż stanowią poważne zagrożenie dla pokoju i bezpieczeństwa międzynarodowego ${ }^{20}$.

Celem niniejszego artykułu jest pokazanie szans i zagrożeń dla Unii Europejskiej po Brexicie oraz jego skutków dla Europy i powstającego na świecie nowego porządku międzynarodowego. Tekst stanowi też próbę odpowiedzi na wiele pytań, m.in.: Jak Brexit wpłynie na rozwój UE, zarówno w aspekcie ekonomicznym, jak i politycznym, oraz na jej pozycję w systemie euroatlantyckim i w ogóle na arenie międzynarodowej? Czy UE stanie się bardziej spójną i aktywną organizacją, zdolną do kontynuowania integracji Europy i umacniania jej roli w nowym porządku globalnym? Jak UE musi się przekształcić, aby odpowiedzieć na zachodzące globalne zmiany i zaspokoić rosnące potrzeby oraz oczekiwania państw członkowskich i ich obywateli? Czy Unii grozi zróżnicowana integracja, a w końcu rozpad? Jakie działania modernizacyjne należy podjąć po Brexicie, aby wzmocnić system polityczny UE i zapobiec jej rozpadowi? Czy Brexit może stać się akceleratorem procesu modernizacji UE? I najważniejsze: czy Brexit przyspieszy rewizję traktatu lizbońskiego i uratuje Unię Europejską?

18 Chiny: będziemy wreszcie numerem 1. Rozmowa z prof. Bogdanem Góralczykiem, "Gazeta Wyborcza” 2017, 20 I, s. 16. Szerzej na ten temat zob. F. Godement, A. Vasselier, China at the Gates: A New Power Audit of EU-China Relations, European Council on Foreign Relations, London, XII 2017.

19 W przemówieniu otwierającym Światowe Forum Ekonomiczne w Davos 23 stycznia 2018 r. premier Indii Narendra Modi przypomniał, że 20 lat temu, kiedy indyjski premier ostatni raz gościł w Davos, wartość PKB tego kraju wynosiła 400 mld dolarów, a dziś - sześć razy więcej. Obiecal, że w 2025 r. PKB Indii będzie wynosić 5 bln dolarów. Patrz P. Macierewicz, Indie stawiają na globalizację i OZE, „Gazeta Wyborcza” 2018, 24 I, s. 11.

20 J.M. Fiszer, Zadania i cele polityki zagranicznej Wtadimira Putina, „Myśl Ekonomiczna i Polityczna” 2016, nr 1, s. 167-201; J. Koralewski, Rozpad ZSRR a powstanie Federacji Rosyjskiej. Mocarstwowość utracona?, [w:] Mocarstwowość na przetomie XX i XXI wieku. Teorie, analizy, prognozy, red. S. Wojciechowski, M. Tomczak, Poznań 2010, s. 129-145; J.M. Fiszer, Czy Rosja pod rządami Wtadimira Putina zagraża Europie i światu?, „Biuletyn Analiz i Opinii” 2015, nr 3, s. 1-10; M. Kokot, Jak Kreml na nowo podbija Europe metodami KGB, „Gazeta Wyborcza” 2017, 13 I, s. 13; J.M. Fiszer, Polityka RFN wobec Rosji - szanse i zagrożenia dla Europy iświata w XXI wieku, „Rocznik Polsko-Niemiecki” 2017, nr 25, z. 1, s. 39-69. 
Tezą główną artykułu jest konstatacja, że Unia Europejska to w dużej mierze struktura reaktywna, a Brexit to potwierdza, co oznacza, że nowe wizje przyszłości dla niej nie są łatwe do opracowania, a jeszcze trudniej będzie je zrealizować w praktyce. Ponadto uważam, że Brexit, którego mimo wszystko nikt się nie spodziewał, będzie stanowił cezurę nie tylko w historii UE, lecz także w dziejach Europy i świata. Sprawi, że wiek XXI nie będzie już wiekiem Zachodu ani wiekiem Europy, ani wiekiem Stanów Zjednoczonych. Będzie wiekiem Wschodu, na czele z Chinami. Ponadto Unia Europejska nadal znajduje się w głębokim kryzysie, który nazywam megakryzysem, i wciąż dryfuje, a Brexit może doprowadzić do katastrofy. Zahamuje bowiem procesy integracyjne w Europie oraz modernizację UE i będzie sprzyjał narastaniu postaw antyunijnych oraz eurosceptycznych. Unia musi teraz uważać, by nie dać Brytyjczykom zbyt dobrych warunków odejścia, aby nie zachęcić kolejnych eurosceptyków. Premier Theresa May mówi bowiem, że celem Londynu jest obecnie gtębokie i specjalne partnerstwo z UE. Ale Unia Europejska musi też załatać dziurę w budżecie po odejściu Londynu - według niedawnych wyliczeń „Financial Times” UE może zażądać nawet 60-100 mld euro od Wielkiej Brytanii. Londyn nie chce jednak przyjąć do wiadomości twardych warunków Brexitu, które stawia Unia Europejska ${ }^{21}$. Wszystko to sprawia, że o kompromis nie będzie łatwo, a „rozwód” Wielkiej Brytanii z Unią Europejską może być bardzo kosztowny dla obu stron i w efekcie dla całej Europy.

\section{WSPÓŁCZESNE PROBLEMY UNII EUROPEJSKIEJ}

Głosowanie społeczeństwa brytyjskiego za opuszczeniem Unii Europejskiej jest jak dotąd najbardziej spektakularnym zjawiskiem dezintegracyjnym, ale podobne tendencje narastają także w innych państwach członkowskich. Dezintegracja Unii przejawia się na wiele innych sposobów. Maleje m.in. współpraca i solidarność silnych ze słabszymi, zwiększają się problemy z implementacją prawa europejskiego, co przyczynia się do jego wymuszania pod presją polityczną i ekonomiczną. Rośnie upolitycznienie Komisji Europejskiej i Rady Europejskiej, a wraz z tym nasila się swobodna interpretacja prawa unijnego przez te instytucje, bardziej wyrozumiałe dla silnych i rygorystyczne dla słabszych państw członkowskich. Unia Europejska już od kilku lat boryka się również z wieloma innymi problemami. Odczuwając wciąż skutki kryzysu finansowo-gospodarczego, musiała się zmierzyć z bezprecedensowym napływem uchodźców i zagrożeniami swojego bezpieczeństwa, zarówno wewnętrznego (liczne zamachy terrorystyczne w zachodnioeuropejskich miastach), jak i zewnętrznego (Państwo Islamskie, agresja Rosji wobec Ukrainy). Co więcej, jedno z jej ważniejszych państw członkowskich - Wielka Brytania - pod wpływem sprawnej kampanii referendalnej populistów i eurosceptyków zdecydowało się opuścić Wspólnotę. Ponadto w społeczeństwach europejskich jak nigdy dotąd wzrosło rozczarowanie Unią Europejską, a sama idea integracji jest stawiana pod znakiem zapytania. Według ostatniego badania Pew Reaserch

21 T. Bielecki, M. Czarnecki, Brexit „nie może być sukcesem”, „Gazeta Wyborcza” 2017, 2-3 V, s. 10. 
Center aż 61\% Francuzów ma nieprzychylną opinię o UE, a tylko 38\% wyraża się o niej pozytywnie. Partie i ruchy polityczne otwarcie kwestionujące istnienie Wspólnoty, takie jak Front Narodowy Marine Le Pen we Francji, niemiecka PEGIDA czy AfD, polskie Prawo i Sprawiedliwość (PiS), doszły do głosu i przejmują władzę w swoich krajach. AfD cieszy się już ponad 13-procentowym poparciem i nie tylko pierwszy raz wprowadziła posłów do Bundestagu (aż 94), lecz także stała się trzecią - po chadekach (CDU/CSU - 32,9\%) i socjalistach (SPD - 20,8\%) - siłą po wyborach parlamentarnych w Niemczech, które odbyły się 24 września 2017 r. ${ }^{22}$

Nie ulega wątpliwości, że dziś UE potrzebuje głębokich reform. Diagnoza ta stała się obowiązującym hasłem obchodów sześćdziesięciolecia traktatów rzymskich, które to obchody odbyły się w marcu $2017 \mathrm{r}$. W przededniu tego wydarzenia pojawiło się wiele raportów, propozycji zmian i scenariuszy na przyszłość, firmowanych przez instytucje unijne i niezależne instytuty. Ich główna teza była taka sama: zreformować i usprawnić Unię Europejską oraz uczynić ją odporną na kryzysy i bardziej otwartą na obywateli i ich problemy. Unia musi wyciągnąć z populistycznego buntu naukę, zanim będzie za późno na przemyślenie projektu europejskiego tak, by mógł on odzyskać swoją legitymację. W tym przypadku hasło Macrona Europe qui protége może być odpowiednim modelem dla nowej Europy, która musi stać się bardziej demokratyczna i zrozumiała dla obywateli. Dziś wielu polityków i ekonomistów, m.in. laureat Nagrody Nobla Joseph E. Stiglitz, podkreśla, że priorytetowym celem UE powinna stać się poprawa pomyślności zwykłych ludzi ${ }^{23}$.

W świetle teorii realistycznej Unia Europejska - dobrowolny związek suwerennych i demokratycznych państw, specyficzna organizacja międzynarodowa - nie jest państwem, ale jest podmiotem prawa międzynarodowego i podmiotem stosunków międzynarodowych. W świetle teorii neofunkcjonalnej Unia jest samonapędzającym się mechanizmem, którego istota polega na tym, że każdy etap jej rozwoju pociąga za sobą konieczność dalszych kroków (spillover), czyli zwiększania jej kompetencji (pogłębiania integracji). Prowadzi to do stałych napięć wywoływanych zakresem i tempem zmian, definiowaniem narodowych interesów oraz pojmowaniem demokracji i suwerenności. Jest to przede wszystkim problem polityczny, w mniejszym stopniu prawny. W relacjach międzynarodowych nie ma jednak i zapewne długo nie będzie światowego parlamentu, sądów czy rządu. Powstanie tego typu instytucji możliwe jest tylko za traktatową zgodą wszystkich państw, co zresztą ma miejsce, ale tylko w ograniczonym rzeczowo lub geograficznie zakresie ${ }^{24}$.

Natomiast z perspektywy teorii gier (gry wielopoziomowej) Unia Europejska jest siłą wewnętrznie skonfliktowaną, gdyż rządy państw członkowskich są uzależnione od narodowych aktorów i w związku z tym mają odmienne postulaty odnośnie do jej

22 B.T. Wieliński, Wielka Rzesza w Bundestagu, „Gazeta Wyborcza” 2017, 16-17 IX, s. 4; tenże, M. Kokot, Kanclerz Merkel po raz czwarty, „Gazeta Wyborcza” 2017, 25 IX, s. 1, 2, 8.

23 J. Stiglitz, Lekcja angielskiego, Obserwatorfinansowy.pl, 18 VII 2016, [online] www.obserwatorfinansowy.pl/tematyka/makroekonomia/lekcja, 23 II 2018.

24 L.S. Finkelstein, What Is Global Governance, „Global Governance” 1995, nr 1, s. 368; J. Czaputowicz, Teorie stosunków międzynarodowych. Krytyka i systematyzacja, Warszawa 2007, s. 354-358. 
polityki wewnętrznej i zagranicznej. Jest to jedna z wielu przyczyn kryzysów, które od lat paraliżują działalność Unii i hamują integrację Europy. W efekcie mamy dziś w UE do czynienia z megakryzysem, na który składają się: kryzys finansowo-gospodarczy, kryzys aksjologii, kryzys zwany deficytem demokratycznym, kryzys integracji Europy, kryzys imigracyjny, kryzys przywództwa i kryzys spowodowany Brexitem. Wynik referendum z 23 czerwca 2016 r., w którym przewagą głosów 51,9\% do 48,1\% obywatele Zjednoczonego Królestwa zdecydowali, że chcą opuścić Unię Europejską, oznacza, że pierwszy raz w historii integracji europejskiej został uruchomiony art. 50 Traktatu o Unii Europejskiej, który umożliwia to jej członkom. Wynik brytyjskiego referendum zaskoczył niemal wszystkich analityków i obserwatorów politycznych, także samych głosujących. Również mnie: byłem przekonany, że pragmatyczni Brytyjczycy zagłosują za pozostaniem państwa w Unii Europejskiej. Okazało się jednak, że ani społeczeństwo, ani część polityków opowiadających się za opuszczeniem UE nie sądziła, że faktycznie do tego dojdzie. W pierwszych sondażach po referendum, kiedy Brexit stał się faktem, aż 84\% Brytyjczyków opowiadało się za pozostaniem w strukturach wspólnoty europejskiej ${ }^{25}$.

Brexit może okazać się punktem zwrotnym w historii UE - początkiem jej rozpadu albo procesu odwrotnego, który przyspieszy reformę i modernizację Unii. Moim zdaniem Brexit osłabi Unię Europejską i zahamuje procesy integracyjne w Europie. Wzrosną bowiem nastroje antyunijne i eurosceptyczne, polegające na krytyce Unii i silnym wobec niej sprzeciwie. Te procesy i zjawiska już trwają i będą się nasilały w poszczególnych państwach członkowskich wraz z brexitowymi negocjacjami. Zgadzam się z tezą niemieckiego analityka, dyrektora Fundacji Współpracy Polsko-Niemieckiej Corneliusa Ochmana, który twierdzi, że:

Czeka nas wstrzas porównywalny z tym, co się dziato po upadku muru berlińskiego w 1989 r. Wówczas też podważono porzadek istniejacy na kontynencie od dziesięcioleci. I nie byto wiadomo, jak rozwinie sie sytuacja. Jednak czuć byto optymizm - byty wyzwania, ale Zachód byt zwycięzca. Teraz przekonanie jest takie, że wszyscy na tym stracimy. A Zachód przestat istnieć jako zwarty blok. Bo w sytuacji, gdy Londyn zdecydowat sie opuścić Unię Europejska, jedność i wynikająca z niej sita Zachodu zostaty podważone. [...] Brexit to ostabienie dla $U E^{26}$.

Już teraz coraz wyraźniej ujawnia się brak jedności i solidarności wśród państw UE. Po 60 latach integracji Europie zabrakło spoiwa i klarownej wizji jej dalszego rozwoju i miejsca w nowym ładzie globalnym. Narastają głębokie podziały i kontestowana jest idea europejskiej solidarności i spójności, a tym samym maleje skuteczność UE jako aktywnego gracza na arenie międzynarodowej ${ }^{27}$. W świetle dramatycznych wydarzeń

25 K. Borońska-Hryniewiecka, Brexit a wtadza ustawodawcza: rola parlamentów Zjednoczonego Królestwa w procesie wychodzenia państwa z Unii Europejskiej, „Sprawy Międzynarodowe” 2016, nr 3, s. 62-77; M. Kaczorowska, Krajobraz polityczny po Brexicie, „Sprawy Międzynarodowe”2016, nr 3, s. 39-61 .

26 Brexit to wyprawa w nieznane. Rozmowa z Corneliusem Ochmanem, „Gazeta Wyborcza” 2017, 30 III, s. 12.

27 J. Zielonka, Koniec Unii Europejskiej?, Polski Instytut Spraw Międzynarodowych, Warszawa 2014, 
w Kijowie, na Krymie i w Donbasie, a także w Syrii i Iraku oraz po wielu zamachach w Paryżu, Londynie, Nicei, Berlinie i Sztokholmie wyraźnie uwidoczniły się liczne mankamenty Unii Europejskiej, a jej prestiż na świecie zmalał. UE stanęła w obliczu wyzwań politycznych, gospodarczych i społecznych, które wymuszają modernizację jej struktur oraz mechanizmów zarządzania i podejmowania decyzji.

Szczególnie niebezpieczny i dotkliwy w skutkach, zarówno dla UE, jak i jej państw członkowskich - zwłaszcza tych należących do strefy euro - okazał się światowy kryzys finansowy. Ukazał on polityczną słabość Unii, wymuszając pytanie o jej spoistość i solidarność. Amerykański ekonomista, noblista Michael Spence twierdzi, że strefa euro ledwo zipie, bo zaszkodziły jej globalizacja, długi i przestarzałe wewnętrzne prawodawstwo. Podkreśla, że Unia pilnie potrzebuje głębokich reform i większej unifikacji w kwestii fiskalnej, finansowej i bankowej oraz zwiększenia dynamiki wzajemnych inwestycji, mobilności kapitału, większych inwestycji w gospodarkę opartą na wiedzy ${ }^{28}$. W pełni zgadzam się z tą opinią. Aby UE mogła się rozwijać, musi stać się unią nie tylko gospodarczą i walutową, lecz także polityczną i społeczną oraz wojskową. Potrzebuje nowego impulsu integracyjnego i nowej, atrakcyjnej wizji, która znowu zjednoczy Europę i zapewni jej godziwe miejsce w nowym porządku światowym.

Unia Europejska stoi dziś przed trudnym i niezmiernie istotnym dylematem: dalszy rozwój i pogłębianie integracji czy ograniczenie jej, spłycenie, a w konsekwencji zmniejszenie znaczenia na arenie międzynarodowej. Ważne decyzje, które nie mogą być odłożone na później, dotyczą kwestii strategicznych, takich jak: tempo rozszerzenia Unii, przyszłość rynku wewnętrznego, bezpieczeństwo energetyczne, problemy demograficzne, w tym związane z migracją ludności i uchodźcami, bezpieczeństwo obywateli oraz zagwarantowanie im korzystania z demokratycznych swobód ${ }^{29}$. Obecnie pilnym wyzwaniem jest konieczność ścisłej współpracy państw członkowskich UE w celu przezwyciężenia negatywnych skutków kryzysu finansowego i gospodarczego oraz tzw. kryzysu uchodźczego. Ideałem byłoby stworzenie sprawnych i skutecznych mechanizmów chroniących UE przed podobnymi problemami w przyszłości. Znalazło to wyraz w Deklaracji Rzymskiej, przyjętej 25 marca 2017 r. podczas szczytu 27 krajów UE z okazji 60. rocznicy podpisania traktatów rzymskich. W dokumencie tym jest mowa o bezprecedensowych wyzwaniach dla Unii - od terroryzmu, przez rosnącą presję migracyjną oraz protekcjonizm, aż po nierówności społeczne i ekonomiczne. Przywódcy UE zobowiązali się do budowania Europy bezpiecznej (m.in. z dobrze chronionymi granicami zewnętrznymi), dostatniej, socjalnej (m.in. walczącej z dyskryminacją, wykluczeniem społecznym i ubóstwem) oraz Europy silniejszej pozycji w kontekście globalnym

s. 27-32; M. Schulz, Skrępowany olbrzym. Ostatnia szansa dla Europy, przeł. R. Formuszewicz, Warszawa 2014.

28 S. Stodolak, Europejska gospodarka dusi się w politycznym pacie, Obserwatorfinansowy.pl, 25 IV 2017 , s. 6, [online] https://www.obserwatorfinansowy.pl/tematyka/makroekonomia/europejska-gospodarka-dusi-sie-w-politycznym-pacie/.

29 Ministerstwo Spraw Zagranicznych, Priorytety polskiej polityki zagranicznej 2012-2016, Warszawa 2012, s. 3-5; A.A. Skrzypek, Kryzys Unii, idei, polityki?, „Politeja” 2016, nr 43, s. 5-41, [online] http:// dx.doi.org/10.12797/Politeja.13.2016.43.01. 
(m.in. wzmacniającej obronność we współpracy z NATO). Europa to nasza wspólna przysztość - brzmi ostatnie zdanie Deklaracji ${ }^{30}$. Niestety, nie zawiera ona konkretnych reform, a więc dopiero z czasem okaże się, czy pozostanie czysto okolicznościowym dokumentem, czy też jej zobowiązania będą wypełnione konkretną treścią i reformami. W Deklaracji nie ma też ani słowa o potrzebie rewizji traktatu lizbońskiego czy o tym, że UE potrzebuje nowego traktatu.

Tymczasem głębokie zmiany i demokratyczne reformy w Unii Europejskiej są niezbędne. W przekonaniu tym utwierdzają mnie wspomniane już wyniki wyborów do Bundestagu w Niemczech z 24 września 2017 r. Pokazują one rosnące w siłę w RFN ugrupowania populistyczne i nacjonalistyczne, które stanowią zagrożenie dla niemieckiej demokracji. Mam nadzieję, że unijni przywódcy i największe unijne stolice pochylą się wreszcie nad przedstawionymi już 1 marca 2017 r. przez przewodniczącego Komisji Europejskiej scenariuszami dalszej integracji i przyszłości Europy ${ }^{31}$. W przedmowie do opublikowanej wówczas Biatej ksieggi w sprawie przysztości Europy Jean-Claude Juncker napisał:

Stoja przed nami poważne wyzwania dotyczace bezpieczeństwa i dobrobytu naszych mieszkańców oraz przysztej roli Europy w coraz wyraźniej zarysowanym wielobiegunowym świecie. Zjednoczona Europa skupiajaca 27 państw musi wziać los we wtasne ręce i zdecydować, jak ma wygladać jej przysztość. [...] Podejmujac decyzje o wyborze przysztej drogi, powinniśmy pamiętać, że największe dokonania Europy zawdzięczamy naszej jedności i odwadze $w$ dziataniu oraz wierze, że jesteśmy w stanie wspólnie budować nasza przysztośc $c^{32}$.

Ale choć minęło już kilka miesięcy od ogłoszenia tych dokumentów, przywódcy Unii nie podjęli żadnych konkretnych działań na rzecz jej sanacji i funkcjonowania po Brexicie. Natomiast przewodniczący Komisji Europejskiej 13 września 2017 r. wygłosił kolejne, pełne ogólników i frazesów „orędzie o stanie Unii Europejskiej”, w którym ponownie podkreślił, że UE musi zrobić ogromny krok naprzód, jeśli chodzi o demokrację i jej przyszłość̉ ${ }^{33}$. Obawiam się jednak, że obecne kierownictwo UE nie jest już w stanie zrobić niczego dla wyprowadzenia jej z megakryzysu, w którym tkwi od wielu lat. Częścią owego megakryzysu jest bowiem kryzys przywództwa UE i miałkość jej elit politycznych, które bardziej dbają o interesy własne niż unijne.

W Unii Europejskiej trzeba jak najszybciej zniwelować istniejący trójpodział na państwa członkowskie, instytucje unijne oraz obywateli, który w ostatnich latach uległ zaostrzeniu i stał się jedną z przyczyn postępującej zróżnicowanej integracji. Unia pilnie

30 Deklaracja Rzymska, „Gazeta Wyborcza” 2017, 27 III, s. 9. Por. także T. Bielecki, Rzymska wiosna w Unii Europejskiej, „Gazeta Wyborcza” 2017, 27 III, s. 9.

31 Biata Księga w sprawie przysztości Europy. Refleksje i scenariusze dotyczące przysztości UE-27 do 2025 r., Komisja Europejska, Bruksela 2017.

32 Tamże, s. 3. Por. także B. Góralczyk, Po 60 latach integracji Europie zabrakto spoiwa, Obserwatorfinansowy.pl, 25 III 2017, s. 1-6, [online] online] https://www.obserwatorfinansowy.pl/tematyka/makroekonomia/po-60-latach-integracji-europie-zabraklo-spoiwa/.

33 President Jean-Claude Juncker's State of the Union Address 2017, European Commission - Speech, 13 IX 2017, [online] http://europa.eu/rapid/press-release_SPEECH-17-3165_en.htm. 
potrzebuje nowych elit i nowego przywództwa oraz nowego myślenia i impulsu integracyjnego; tylko „ucieczka do przodu” może ją uratować przed rozpadem i zwiększyć jej rolę na arenie międzynarodowej. W kontekście powyższego można stwierdzić, że Unia Europejska potrzebuje też nowego traktatu, który uzdrowi jej system społeczno-polityczny i gospodarczy, usprawni proces decyzyjny oraz umocni jej rolę na świecie. Brexit może tu odegrać ważną rolę, mianowicie stać się pretekstem i akceleratorem do rewizji traktatu lizbońskiego.

$\mathrm{Z}$ drugiej strony, wbrew europesymistom, Unia Europejska - co chciałbym zaznaczyć - mimo wielu kryzysów i problemów związanych z Brexitem nadal pozostaje największą w świecie wspólnotą, łączącą cechy organizacji międzynarodowej oraz federalnej struktury państwa związkowego. Posiada atrybuty aktora światowego i kompetencje do aktywnego uczestnictwa w stosunkach międzynarodowych. Dysponuje specyficzny$\mathrm{mi}$ instrumentami, niezbędnymi do działań międzynarodowych, w tym własną dyplomacją. Tego nie wolno zaprzepaścić. UE po Brexicie powinna więc zmierzać nie tylko do utrzymania, lecz także do zwiększenia swojej obecności i aktywności we wszystkich regionach świata. Powinna w sposób racjonalny łączyć politykę handlową, pomoc rozwojową i humanitarną z rozszerzającą się działalnością polityczno-dyplomatyczną, tak jak to czynią od lat Stany Zjednoczone i Chiny. Dzięki temu, mimo Brexitu, Unia Europejska mogłaby stać się ważnym stabilizatorem i ośrodkiem politycznego oddziaływania na skalę globalną i wpływać na kształt nowego porządku międzynarodowego, będąc zarazem jednym z jego głównych biegunów. Ale do realnego zwiększenia tego statusu UE musi się pogłębiać i poszerzać; potrzebuje nie tylko autonomicznego systemu militarno-obronnego, lecz także bardziej zdecydowanego przywództwa.

\section{POZYTYWNE I NEGATYWNE SKUTKI BREXITU DLA UNII EUROPEJSKIEJ}

Lata 2008-2017, a zwłaszcza kryzys finansowo-gospodarczy, konflikty i wojny na Ukrainie, na Bliskim Wschodzie i w Afryce Północnej, kryzys imigracyjny oraz liczne zamachy terrorystyczne dobitnie uświadomiły Europie (UE w szczególności), że koniec historii, w który uwierzono po upadku muru berlińskiego i rozpadzie ZSRR, był złudzeniem. Po upadku muru berlińskiego w 1989 r. świat trwał w stanie euforii. Wielu dało wiarę teoriom amerykańskiego politologa Francisa Fukuyamy o końcu historii i triumfalnym pochodzie liberalnej demokracji przez świat. Po ćwierćwieczu pełnym nadziei i rozczarowań historia zatoczyła koło. Euforia skończyła się wraz z kryzysem finansowo-gospodarczym w latach 2008-2014. Ostatnie lata to ponowny marsz konserwatyzmu przez świat, renesans nacjonalizmu, a wraz z nim ksenofobii, podsycanej wszechobecną retoryką religijną. To zarazem odwrót od idei integracyjnych w Europie i nasilanie się tendencji dezintegracyjnych na świecie. Triumfalizm i nadzieja na „wieczny pokój” skończyły się, a wiara w stopniową, lecz nieuchronną demokratyzację kolejnych państw i społeczeństw została mocno nadwątlona. W świetle dramatycznych wydarzeń w Kijowie, na Krymie i w Donbasie, a także w Syrii, Iraku, Paryżu, Berlinie, 
Sztokholmie i Turcji (pucz), wyraźnie uwidoczniły się liczne mankamenty Unii Europejskiej oraz uległ osłabieniu jej prestiż na świecie. Perspektywy rozwoju oraz pokój i bezpieczeństwo Europy są dziś, 13 lat po wielkim rozszerzeniu UE na wschód, poważnie zagrożone.

Obecnie Unia Europejska jest podzielona i de facto nie ma wspólnej polityki zagranicznej i obrony, a inne jej polityki, np. imigracyjna, są mało skuteczne. Unią faktycznie rządzą Niemcy i Francja. Trzeba jednak pamiętać, że Unia Europejska od momentu powstania, czyli od podpisania traktatu z Maastricht, starała się być tylko mocarstwem normatywnym. Traktat ten istotę tożsamości UE sprowadzał do walki o utrzymanie pokoju i bezpieczeństwa oraz na rzecz rozwijania współpracy międzynarodowej zgodnie z aksjologią Unii i Kartą Narodów Zjednoczonych. Nadrzędnym celem UE stało się popieranie demokracji, rządów prawa, praw człowieka i podstawowych wolności. W tym zakresie aktywność UE była niezrównana i przyniosła spore efekty, zwłaszcza w czterech obszarach: handlu, praw człowieka, bezpieczeństwa oraz ochrony środowiska naturalnego i ziemskiego klimatu.

Po pierwszych sukcesach tworzenie wspólnej polityki bezpieczeństwa i obrony choć zgodnie z przyjętą w 2003 r. strategią bezpieczeństwa UE miała być zdolna do współodpowiedzialności za globalne bezpieczeństwo i budowę lepszego świata - uległo wyhamowaniu. Złożyło się na to wiele przyczyn. Kwestie wiążące się z wykorzystaniem zasobów wojskowych, a do pewnego stopnia także pozamilitarnych państw członkowskich do budowy międzynarodowej stabilności i bezpieczeństwa, z jednej strony dotykają sfer tradycyjnie uznawanych za jądro suwerenności państw i ich najbardziej fundamentalnych interesów, z drugiej zaś wiążą się z dużymi nakładami finansowymi. To powoduje, że stosunkowo słabo poddają się one procesom integracyjnym, zachowując w znacznej mierze tradycyjny, międzyrządowy kształt. Znalazło to wyraz choćby w instytucjonalnym kształcie Wspólnej (dawnej Europejskiej) Polityki Bezpieczeństwa i Obrony UE (WPBiO) oraz obowiązujących w jej ramach procesów decyzyjnych, wciąż wymagających konsensusu wszystkich państw uczestniczących. Wydaje mi się, że to jedna z głównych przyczyn relatywnie ograniczonego, zwłaszcza na tle pozostałych dziedzin integracji europejskiej, rozwoju współpracy w sferze obronności w ramach Unii Europejskiej. Podczas wojny z Irakiem Stanom Zjednoczonym udało się podzielić UE i powstrzymać jej starania o strategiczną autonomię i podmiotowośćc ${ }^{34}$. Reszty dokonał kryzys finansowo-gospodarczy po 2008 r., a także sprzeciw lub brak zainteresowania różnych państw unijnych. Kryzys osłabił Francję, która przestała być pełnowartościowym partnerem RFN, i w jeszcze większym stopniu Włochy, a Londyn ogłosił zamiar zmniejszenia swej obecności w UE i wyznaczył na 23 czerwca 2016 r. referendum w sprawie dalszej obecności Wielkiej Brytanii w strukturach Unii. Brexit stał się faktem. Tymczasem Niemcy nie potrafity - i oficjalnie nadal nie chcą - zapewnić UE politycznego przywództwa. Gdy więc w okresie rządów Obamy Europa otrzymała od zwracającego się ku Azji Waszyngtonu zielone światło dla autonomicznych działań

34 H. Świętek, Wojna z Irakiem w 2003 roku. Gtówne przyczyny, Warszawa 2011; S. Zarychta, Doktryny i strategie NATO 1949-2013, Warszawa 2014. 
w sprawach bezpieczeństwa, podzieleni i nieskorzy do wysiłku zbrojnego Europejczycy stracili zapał i nie skorzystali z okazji do wzmocnienia UE i jej roli w budowie nowego porządku międzynarodowego. W konsekwencji Europa nie stanowi dziś wielkiej, niezależnej potęgi w skali globalnej i niewielu spodziewa się, że Unia Europejska w najbliższym czasie osiągnie rangę politycznie istotnego, globalnego gracza; przodująca rola Stanów Zjednoczonych również wydaje się niepewna ${ }^{35}$.

Odejście Wielkiej Brytanii z UE niewątpliwie w istotny sposób osłabi całą Wspólnotę, która nie była przygotowana na taki scenariusz. Po Brexicie, w nowych warunkach geopolitycznych i geoekonomicznych na świecie, jeszcze większą niż dotychczas rolę będą w UE odgrywały Niemcy. Odwołując się do paradygmatu szkoły angielskiej, można stwierdzić, że to RFN ma największe szanse na uzyskanie pozycji hegemona w naszym regionie, czyli w Europie Środkowej. Niemcy są mocarstwem regionalnym, a nawet liderem w Europie, zdolnym do prowadzenia polityki zagranicznej o zasięgu globalnym. Już dzisiaj, z PKB sięgającym 3,1 bln euro, są najsilniejszą gospodarką Unii Europejskiej, wytwarzającą 21,1\% unijnego PKB. Wielu ekspertów prognozuje, że ok. 2050 r. RFN stanie się mocarstwem globalnym. Niemiecka składka do unijnego budżetu wzrośnie o ok. 2,5 mld euro. Biorąc pod uwagę sytuację Francji, zmagającej się od dłuższego czasu $\mathrm{z}$ wieloma problemami wewnętrznymi i zewnętrznymi, można stwierdzić, że Niemcy staną się bezsprzecznym liderem UE. Skorzystają one na Brexicie, m.in. dzięki inwestorom opuszczającym Zjednoczone Królestwo. Jeszcze niedawno siedzibą spółki powstałej po fuzji giełd w Londynie i Frankfurcie nad Menem miała być brytyjska stolica; teraz znów jest możliwe, że będzie to Frankfurt. Już następnego dnia po decyzji Brytyjczyków o opuszczeniu Unii miasto uruchomiło adresowaną do londyńskiego City stronę internetową, na której wyliczało swoje walory i wskazywało, że jest jedynym na świecie miejscem z siedzibą dwóch banków centralnych: Bundesbanku i Europejskiego Banku Centralnego (ECB), nie mówiąc już o niemieckim nadzorze finansowym - BaFin. Ta niemiecka metropolia może zyskać także na innych przeprowadzkach z londyńskiego City, ale będzie musiała o to rywalizować z Paryżem i Dublinem. Szacuje się, że wskutek exodusu instytucji finansowych z Londynu w konsekwencji Brexitu Frankfurt może zyskać prawie 100 tys. nowych miejsc pracy ${ }^{36}$.

Wzmocnienie niemieckiej dominacji w Europie, przy jednoczesnym osłabieniu procesu europejskiej integracji, nie jest jednak dobrą wiadomością dla Starego Kontynentu, w tym także dla Polski. Brexit doprowadzi bowiem do zachwiania politycznej równowagi, którą w pewnym stopniu stanowiła Wielka Brytania dla niemiecko-francuskiego tandemu. Opuszczenie przez Wielką Brytanię UE oznaczać będzie także wycofanie się tego państwa ze wspólnej polityki zagranicznej i bezpieczeństwa (WPZiB) tej organizacji, jak również ze stanowiącej jej integralną część wspólnej polityki bezpieczeństwa i obrony (WPBiO). Znacząco osłabi to wymiar obronny UE, stawiając zarówno Niemcy, jak

35 Kryzys 2008 a pozycja międzynarodowa Zachodu, red. R. Kuźniar, Warszawa 2011; Z. Brzeziński, Strategiczna wizja. Ameryka a kryzys globalnej poteggi, przeł. K. Skonieczny, Kraków 2013.

36 M. Ciesielski, Frankfurt może zostać największym beneficjentem Brexitu, Obserwatorfinansowy.pl, 31 VIII 2017, s. 1-3, [online] https://www.obserwatorfinansowy.pl/tematyka/rynki-finansowe/ frankfurt-moze-zostac-najwiekszym-beneficjentem-brexitu/. 
i pozostałe państwa członkowskie przed kolejnym poważnym wyzwaniem związanym z koniecznością wzięcia dużo większej niż dotychczas odpowiedzialności za wspólne bezpieczeństwo i obronę na szczeblu europejskim, bez względu na trwającą równolegle intensywną dyskusję dotyczącą przyszłości NATO i stanowiska prezydenta Trumpa w tej sprawie, które wciąż nie jest jasno sprecyzowane. Z drugiej strony Wielka Brytania niejednokrotnie blokowała w przeszłości inicjatywy wzmacniające współpracę w ramach WPBiO, obawiając się powstania systemu konkurencyjnego wobec $\mathrm{NATO}^{37}$.

W rezultacie po brytyjskiej decyzji o Brexicie pojawiły się kolejne przesłanki do większej koordynacji współpracy w dziedzinie bezpieczeństwa i obrony pozostałych 27 członków UE, o co apelowali m.in. ówcześni ministrowie spraw zagranicznych Niemiec oraz Francji, Frank-Walter Steinmeier i Jean-Marc Ayrault we wspomnianym już manifeście Silna Europa w niepewnym świecie ${ }^{38}$. Jeśli tak się nie stanie, to Europa będzie musiała porzucić nadzieje na stworzenie świata na swój obraz i podobieństwo. UE na arenie międzynarodowej nie może wciąż być tylko gospodarczą potęgą i politycznym karłem - Xi Jinping, Narendra Modi, Władimir Putin i Recep Tayyip Erdoğan mogą być jej taktycznymi partnerami, ale nie będą sojusznikami w obronie liberalnego porządku na świecie. Porządek ten został zresztą zakwestionowany w obrębie samej UE przez rozkwit partii buntu wykorzystujących obawy i niepewność, wywołane przez migracje i wolny handel. Błędem jest twierdzenie, że wiek XXI jest wiekiem geoekonomii. Odwoływanie się więc w polityce międzynarodowej UE tylko do soft power dziś już nie wystarcza. UE potrzebuje też twardej siły, ale postrzeganie siły ekonomicznej jako poważnej części hard power może okazać się mało skuteczne (choć ma znaczenie w wymiarze soft). Okazuje się, że to siła wojskowa w olbrzymim stopniu tworzy hard power i nadal pozostaje ważnym elementem polityki. W pewnych wypadkach użycie siły militarnej w sposób tradycyjny, przez znaczący podmiot międzynarodowy, przypomina o istocie siły oraz uznaniu jej w programach bezpieczeństwa czy też nakreślaniu strategii użycia określonych środków polityki zagranicznej" ${ }^{39}$.

Chciałbym podkreślić, że - jak pokazuje praktyka międzynarodowa - wraz z umacnianiem się potęgi ekonomicznej i militarnej rośnie pewność siebie i przekonanie o wyższości własnej kultury, wartości instytucji państwa czy organizacji, czyli to, co można określić jako źródło siły miękkiej. Dla innych narodów staje się ona atrakcyjniejsza. Jednocześnie wraz ze słabnięciem potęgi gospodarczo-militarnej następuje zwątpienie we własne siły, kryzys tożsamości, szukanie klucza do sukcesów w innych

37 Por. K. Szubart, Unia Europejska „dwóch prędkości”? Niemcy i WPBiO po Brexicie, „Biuletyn Instytutu Zachodniego" 2016, nr 281, s. 1 i nast.

38 Tamże. Zob. także H. Friederichs, Der Stärkste steigt aus, „Zeit Online” 2016, 1 VIII, [online] http:// www.zeit.de/politik/2016-08/grossbritannien-sicherheitspolitik-brexit-eu/komplettansicht, 10 III 2017.

39 Szerzej na ten temat zob. R. Cooper, Hard Power, Soft Power and the Goals of Diplomacy, [w:] American Power in the $21^{\text {st }}$ Century, red. D. Held, M. Koenig-Archibugi, Cambridge-Malden 2004, s. 168; R.O. Keohane, J.S. Nye, Power and Interdependence. World Politics in Transition, Boston-Toronto 1977, s. 26-29; R. Smith, Przydatność sity militarnej. Sztuka wojenna we wspótczesnym świecie, Warszawa 2010 . 
systemach i kulturach. Można więc założyć, że siła (władza, polityka) miękka jest skuteczna tylko wówczas, jeśli znajduje oparcie w sile twardej, a tej w Unii Europejskiej zabrakło. Relacje twardej i miękkiej siły dość dobrze określił Niall Ferguson, który uznał soft power za delikatna rękawiczkę leżąca na żelaznej ręce $e^{40}$.

Unijni przywódcy muszą więc zachować realizm i skupić się na obronie marzenia o mocno ugruntowanym liberalnym ładzie wewnątrz Unii Europejskiej, godząc się na powrót do jego słabszej wersji w pozostałej części świata. W polityce zewnętrznej oznacza to gotowość do pracy z istniejącymi reżimami zamiast uciekania się do moralizatorstwa, np. w postaci nawoływania, że Putin musi odejść. Oznacza to też uświadomienie sobie, że UE nie jest jedynym biegunem sąsiedztwa wschodniego. Unia może wspierać stabilne rządy w Gruzji, Ukrainie i Mołdawii, ale nie powinna postrzegać ich jako przyszłych państw członkowskich.

Istnieje również potrzeba przywrócenia zaufania nie tylko między obywatelami a rządami, ale także między samymi rządami. Wobec najgłębszych od pokolenia podziałów między państwami członkowskimi największą nadzieję na głębszą integrację daje elastyczna konfiguracja koalicji skupiających różne państwa wokół różnych problemów (tematów). Europa kręgów koncentrycznych - z Niemcami i Francją w centrum - moim zdaniem nie przywróci solidarności, gdyż wiele podziałów występuje w ramach strefy euro i Schengen, a nie pomiędzy różnymi kręgami. Niemniej jednak Niemcy i Francja są kluczowe dla odbudowy projektu europejskiego. Niemcy - jak już wspominałem - zaczęły rozumieć swoją rolę i ponosić większą odpowiedzialność za własne bezpieczeństwo, obiecując jeszcze w 2017 r. zwiększyć o 8\% wydatki na obronę. Ale RFN powinna też być bardziej elastyczna i gotowa do współpracy poza instytucjami unijnymi oraz wykazywać mniej rygorystyczne podejście do zasad ekonomicznych i interpretacji przepisów. Z kolei prezydent Macron mógłby pomóc zasypać niektóre z podziałów w Europie, np. poprzez połączenie mocnych środków antyterrorystycznych z bardziej humanitarnym podejściem do uchodźców. Dla sparaliżowanej dziś przez spory UE wielkie porozumienia en même temps proponowane przez Macrona mogą wskazać drogę naprzód, której tak bardzo Unia dziś potrzebuje ${ }^{41}$.

Natomiast w polityce wewnętrznej UE po Brexicie ważkim zadaniem jest wyciągnięcie wniosków z populistycznego buntu, zanim będzie za późno na przemyślenie projektu europejskiego tak, by mógł on odzyskać swoją legitymację. Przywódcy Unii muszą zrozumieć, że to właśnie współzależność, którą UE starała się osiągnąć i która stała się faktem poprzez jej działania (np. za pośrednictwem euro, swobodnego przepływu, ale także w obliczu zjawiska terroryzmu), prowadzi do poczucia bezsilności i bezbronności. Dzisiaj przetrwanie Unii zależy od potwierdzenia, że jest ona w stanie ochronić Europejczyków przed siłami, które sama promowała. UE powinna m.in. zbadać, jak chronić swoich obywateli przed dotykającym konkretne regiony negatywnym

40 N. Ferguson, Colossus. The Price of America's Empire, New York 2004, s. 24.

${ }_{41}$ M. Leonard, L'Europe qui Protége: Conceiving the Next European Union, European Council on Foreign Relations, VIII 2017, [online] http://www.ecfr.eu/publications/summary/leurope_qui_protege_conceiving_the_next_european_union, 22 IV 2018. 
wpływem migracji na usługi publiczne i płace. Można to zrobić poprzez dostosowanie alokacji funduszy, z których popłyną środki do regionów i miast szczególnie dotkniętych migracją, umożliwiając im inwestowanie w budowę szkół i szpitali oraz zapewnienie większej ilości usług społecznych ${ }^{42}$.

Pilnym zadaniem dla UE jest także powstrzymanie tendencji dezintegracyjnych w Europie. W tym celu Unia powinna zmierzać w dwóch kierunkach. Po pierwsze, zrewidować politykę oszczędności oraz zwiększyć skalę inwestycji w państwach słabiej rozwijających się lub pogrążonych w kryzysie. Po drugie, rozwiązać istniejący od lat problem deficytu demokracji. Oznacza to albo wprowadzenie pełnej demokracji (federacji demokratycznej) w UE, albo oddanie kompetencji unijnych z powrotem do państw, czyli tam, gdzie istnieje demokratyczna kontrola nad władzą. Niestety, kanclerz Merkel, która dziś rządzi Unią Europejską, odrzuca ideę federacji i promuje międzyrządową wspólpracę państw. Sprzyja ona interesom najsilniejszych podmiotów, a także podporządkowuje tej logice całe instrumentarium prawa i instytucji UE. Elity polityczne UE odrzucają też w większości rewizję traktatową, głównie z obawy przed narodową demokracją, a dokładnie możliwością sprzeciwu wyborców wobec integracji w kolejnych referendach. Bardzo mało prawdopodobna jest też znacząca renacjonalizacja kompetencji unijnych, czego notabene od lat bezskutecznie domagali się Brytyjczycy. W związku z tym prawdopodobnie nastąpi zacieśnienie kolejnych reżimów gospodarczych i politycznych, zwłaszcza tych, które przynoszą korzyści najsilniejszym państwom. To zaś spowoduje ekspansję prawa unijnego, ale bez konieczności zmiany traktatów. Wzmocnieniu ulegnie strefa euro, ale bez zasadniczego pogłębiania unii politycznej. Duże zmiany będą dotyczyły nowego budżetu wspólnoty. Przede wszystkim zmniejszy się finansowanie polityki spójności, a środki zostaną przeniesione na innowacje wojskowe, politykę migracyjną i wsparcie strefy euro, co nie jest korzystnym rozwiązaniem dla państw spoza strefy euro, w tym Polski ${ }^{43}$.

W sytuacji, gdy UE musi stawiać czoła wewnętrznym i zewnętrznym problemom, pogłębionym przez Brexit, które stawiają pod znakiem zapytania jej dalsze istnienie, coraz głośniej mówi się także o Unii wielu prędkości i elastycznej współpracy, czyli zróżnicowanej integracji jako panaceum na aktualną sytuację. Kanclerz Merkel już wiele razy mówiła, że powstanie Unia Europejska wielu prędkości. A Macron w trakcie kampanii wyborczej i już po zaprzysiężeniu go na stanowisko prezydenta Francji wielokrotnie wspominał o konieczności pogłębiania integracji i przyszłej federalizacji Europy. Także przewodniczący Komisji Europejskiej w ogłoszonej w marcu 2017 r. Biatej księdze w sprawie przysztości Europy zaproponował większą elastyczność jako jedną z pięciu potencjalnych dróg dla przyszłej współpracy krajów UE ${ }^{44}$. Koncepcja ta zakłada skupienie się Unii Europejskiej na określonych, priorytetowych obszarach współpracy, w których będzie ona

\section{Tamże.}

43 T.G. Grosse, Kryzys po Brexicie, „Rzeczpospolita” 2016, 15 VII, s. A11.

44 Biata Ksiegga w sprawie przysztości Europy..., s. 23-24; A. Fuksiewicz, Przysztość Unii Europejskiej przegląd propozycji, Instytut Spraw Publicznych, Warszawa 2016, s. 46; J. Majmurek, Dat nam przyktad Macron, jak zwycieżać mamy, „Gazeta Wyborcza” 2017, 12 V, s. 15. 
działać szybciej i skuteczniej, a jednocześnie znacznie zmniejszy zaangażowanie w innych obszarach. Obszarami priorytetowymi miałyby być m.in. innowacje, handel, bezpieczeństwo, migracje i zarządzanie granicami czy obronność, a także dekarbonizacja i cyfryzacja. Natomiast UE wielu prędkości, która jest już faktem (nie wszystkie bowiem państwa należą do strefy Schengen czy strefy euro), ma umożliwić „koalicjom chętnych państw" zacieśnianie współpracy bez względu na zainteresowanie innych krajów. Ten właśnie scenariusz ma dać największe szanse na zachowanie jedności UE przy utrzymaniu możliwości dalszej integracji, ale może też prowadzić do chaosu i zróżnicowania praw obywateli Wspólnoty w zależności od tego, z jakiego państwa członkowskiego pochodzą. Według Komisji Europejskiej państwa pozostające poza nowymi (priorytetowymi) obszarami współpracy zachowają prawo włączenia się w nie w przyszłości.

Moim zdaniem po Brexicie przywódcy UE powinni kierować się zdrowym rozsądkiem i realistycznym podejściem do obecnych problemów i wyznaczyć skuteczną drogę jej dalszego rozwoju. Droga ta powinna być dwuetapowa; etap pierwszy to kontynuacja dotychczasowych reform, etap drugi - nowy, jakościowy rozwój UE. Reformy UE powinny odpowiadać na pojawiające się kryzysy oraz problemy gospodarcze, społeczne, polityczne i związane z bezpieczeństwem. Państwa członkowskie powinny też wspólnie zdecydować o przekazaniu kolejnych kompetencji na poziom unijny, a decyzje muszą być podejmowane sprawniej i szybciej wprowadzane w życie. UE musi mówić jednym głosem na arenie międzynarodowej i mieć do dyspozycji hard power, czyli siłę militarną, która wzmocniłaby bezpieczeństwo Europy i jej rolę w przyszłym wielobiegunowym ładzie globalnym. W tym celu niezbędne jest powstanie Europejskiej Unii Obronnej.

$\mathrm{Z}$ polskiego punktu widzenia niebezpieczny jest scenariusz UE wielu prędkości, który grozi nam tzw. członkostwem drugiej kategorii i pozostaniem poza głównym nurtem integracji. Przykładowo integracja sektora bankowego w ramach strefy euro może prowadzić do dezintegracji na rynku wewnętrznym w bankowości między krajami w strefie euro i poza nią. Z punktu widzenia całej UE może to grozić utratą spójności, chaosem decyzyjnym i kontrowersjami politycznymi, a także umocnieniem się wymiaru międzyrządowego współpracy. Przy braku ogólnego konsensusu państw co do kierunku rozwoju UE w pewnym stopniu ten scenariusz może być realizowany. $\mathrm{Z}$ punktu widzenia Polski jest to argument polityczny za przystąpieniem do strefy euro, co byłoby gwarancją utrzymania się w głównym nurcie integracji.

Konkludując rozważania o skutkach Brexitu dla Unii Europejskiej, można stwierdzić, że z jednej strony stanowi on dla niej wielkie wyzwanie, wręcz stawia przed nią pytania natury egzystencjalnej, a z drugiej - jest szansą na jej modernizację i dalszy rozwój. Wbrew Brexitowi i eurosceptykom, którzy pozostają mocni, ostatnie sondaże Eurobarometru pokazują, że coraz więcej Europejczyków, w tym również Brytyjczyków, uważa, że członkostwo w Unii Europejskiej jest czymś dobrym (średnio 57\% wyraża opinię, że członkostwo jest dobre, co stanowi wzrost o cztery punkty procentowe w stosunku do 2016 r.; w przypadku Polski: 71\%, wzrost o dziesięć punktów procentowych) ${ }^{45}$.

45 Por. Two Years until the 2019 European Election. Special Eurobarometr of the European Parliament, European Parliamentary Research Service, IV 2017; A. Fuksiewicz, Przysztość Unii Europejskiej..., s. 12. 


\section{ZAKOŃCZENIE}

Wyniki brytyjskiego referendum z 23 czerwca 2016 r. zaskoczyły elitę polityczną Unii Europejskiej i całej Europy, która do końca wierzyła w sukces zwolenników pozostania Wielkiej Brytanii w UE, próbując stosować wobec Londynu metodę kija i marchewki. Sukces przeciwników UE w tym kraju wywołał strach przed negatywnymi skutkami politycznymi, społecznymi, a także gospodarczymi i międzynarodowymi, które może przynieść Brexit państwom członkowskim Unii i w ogóle całej Europie. Obawy te szczególnie dają o sobie znać w Wielkiej Brytanii, RFN i Francji ${ }^{4}$, a także w Polsce. Dotyczą dalszego wzrostu popularności ugrupowań eurosceptycznych i nacjonalistycznych oraz przyszłości Unii Europejskiej i losów prawie miliona Polaków na Wyspach Brytyjskich $^{47}$.

Bez względu na inne kryzysy, do których od lat dochodzi na Starym Kontynencie, wystąpienie Wielkiej Brytanii z UE osłabi tę organizację w wymiarze gospodarczym, militarnym oraz politycznym, co może przynieść negatywne konsekwencje zarówno dla Wielkiej Brytanii, której grozi rozpad, jak i dla całej UE, stojącej obecnie przed podobnym zagrożeniem. W osłabionej Unii jeszcze większą rolę niż dotychczas będą odgrywały Niemcy, dla których Wielka Brytania stanowiła do pewnego stopnia przeciwwagę w tej organizacji. Dalszy wzrost niemieckiej pozycji w UE, przy jednoczesnym osłabieniu jej roli w tworzącym się obecnie wielobiegunowym ładzie międzynarodowym, nie wróży dobrze nie tylko samym Niemcom, lecz także pozostałym unijnym partnerom ${ }^{48}$.

Summa summarum na Brexicie, zwłaszcza źle przeprowadzonym, stracić mogą wszystkie zainteresowane strony. Obok zagrożeń niesie on też jednak pewne szanse dla UE i jej państw członkowskich. Brexit może bowiem stanowić dobry pretekst do wdrożenia wcześniej przygotowywanych reform, które pogłębią integrację i przyspieszą modernizację Unii Europejskiej. Brexit może też przyspieszyć rewizję traktatu z Lizbony i radykalnie zmienić UE, zwłaszcza jeśli chodzi o jej system polityczny i sposób podejmowania decyzji. Mówił o tym 13 września 2017 r. szef Komisji Europejskiej w orędziu o stanie Unii Europejskiej ${ }^{49}$.

46 Nic dziwnego, bo - jak wynika z danych Eurostatu - produkt krajowy brutto UE w 2016 r. wyniósł 14,8 bln euro, a ponad połowę tej kwoty wygenerowały trzy państwa członkowskie: Niemcy, Wielka Brytania i Francja. Polska z PKB na poziomie 424,6 mld euro uplasowała się na 8. miejscu w UE (2,9\% unijnego PKB).

47 Plan schładzania entuzjazmu Polaków wobec UE, który wiosną 2017 r. zapowiadał minister Witold Waszczykowski, zupełnie się jednak nie powiódł. Jak pokazują badania opinii publicznej, przeprowadzone w grudniu 2017 r. przez firmę Kantar Millward Brown, aż 83\% respondentów wciąż opowiada się za członkostwem Polski w Unii Europejskiej. Zob. P. Zalewski, Osamotniona Polska, rp.pl, 22 I 2018, [online] http://www.rp.pl/Publicystyka/301229926-Pawel-Zalewski-Osamotniona-Polska.html, 16 IV 2018.

48 K. Dadak, Intermarium - plan B dla Polski po Brexicie?, „ARCANA” 2016, nr 4, s. 16-30.

49 President Jean-Claude Juncker's State... Zob. także T. Bielecki, Nie stój, nie czekaj, urządź sobie lepsza Europe, „Gazeta Wyborcza” 2017, 16-17 IX, s. 4. 
Instytucje UE są anachroniczne, a wielu obywateli nawet nie wie, jak one działają, i wierzy, że Europą rządzi odległa, technokratyczna Bruksela wraz z oderwanymi od realiów urzędnikami. Paradoksalnie mają rację: jak pokazuje praktyka, rozwój integracji w Europie już od dawna odbywa się kosztem demokracji i obywateli. Unia Europejska oderwała się od obywateli i nie rozwiązuje ich problemów. Osłabia to wiarygodność unijnych instytucji i prawa europejskiego, które dotąd były fundamentem integracji. Efektem tego stał się również Brexit, będący de facto buntem wielu Brytyjczyków przeciwko unijnemu establishmentowi i jego neoliberalnej polityce społeczno-gospodarczej.

Trudno więc opracować trafną prognozę dotyczącą skutków Brexitu dla Unii Europejskiej i jej państw członkowskich. Brexit bowiem może okazać się punktem zwrotnym w historii UE - początkiem jej rozpadu albo procesu odwrotnego. Natomiast podzielona, skłócona i nacjonalistyczna Europa - bez UE czy ze słabą Unią - przestanie odgrywać istotną rolę w systemie euroatlantyckim i w nowym ładzie globalnym. Stanie się jego peryferiami, narażonymi na liczne niebezpieczeństwa ze strony takich mocarstw, jak Chiny, Rosja czy Niemcy.

Polska jako państwo peryferyjne, rozerwane między Wschodem i Zachodem, którego pozycja znajduje się poza rdzeniem społeczności międzynarodowej, w obecnej sytuacji w Europie i na świecie powinna prowadzić realistyczną politykę, tzn. nie ulegać złudzeniom i twardo stąpać po ziemi. Polska nie może opuścić ani UE, ani NATO. Wciąż jesteśmy krajem słabym, na dorobku, wewnętrznie skłóconym i z podzielonym narodem. A tymczasem otaczają nas kraje wrogie lub takie, które nie życzą nam najlepiej. Do tych drugich można śmiało zaliczyć Ukrainę i Litwę, a do pierwszych Białoruś, Rosję i Niemcy. Słowacy i Czesi nas tolerują, ale wątpię, aby nas kochali. Na pewno nie będą za nas ginęli. Bliżej im do Niemiec i Rosji niż do Polski. Zaś Niemcy i Rosja mogą znaleźć wspólny język i rozwijać współpracę ponad Polską lub jej kosztem. Rosjanie już dawno sprzęgli interesy z Niemcami, zwłaszcza w sferze gospodarczej. Świadczą o tym gazociągi Nord Stream 1 i 2 oraz liczba bezpośrednich inwestycji zagranicznych, które Niemcy lokują w Rosji mimo nałożonych na nią przez UE sankcji ekonomicznych za aneksję Krymu.

\section{BIBLIOGRAFIA}

Afanasjew J., Groźna Rosja, przel. M. Kotowska, Warszawa 2004.

Applebaum A., Merkel góra, ale skrajna prawica naciera, przeł. A. Ehrlich, „Gazeta Wyborcza” 2017, 20 IX.

Bagniewska J., Naukowcy kontra Brexit, „Gazeta Wyborcza” 2017, 4 V.

Biata Ksiega w sprawie przysztości Europy. Refleksje i scenariusze dotyczace przysztości UE-27 do 2025 r., Komisja Europejska, Bruksela 2017.

Bielecki T., Nie stój, nie czekaj, urządź sobie lepsza Europę, „Gazeta Wyborcza” 2017, 16-17 IX. Bielecki T., Rozwód z Londynem pod górkę, „Gazeta Wyborcza” 2017, 15 IX.

Bielecki T., Rzymska wiosna w Unii Europejskiej, „Gazeta Wyborcza” 2017, 27 III. 
Bielecki T., Czarnecki M., Brexit „nie może być sukcesem”, „Gazeta Wyborcza” 2017, 2-3 V.

Bieleń S., Wizerunki międzynarodowe Rosji, „Polityka Polska” 2016, nr 5-6.

Borońska-Hryniewiecka K., Brexit a wtadza ustawodawcza: rola parlamentów Zjednoczonego

Królestwa w procesie wychodzenia państwa z Unii Europejskiej, „Sprawy Międzynarodowe” 2016, nr 3.

Brexit to wyprawa w nieznane. Rozmowa z Corneliusem Ochmanem, „Gazeta Wyborcza” 2017, 30 III.

Bryc A., Europejska Polityka Sasiedztwa w perspektywie rosyjskiej, [w:] Europejska Polityka Sasiedztwa Unii Europejskiej. Geneza, doświadczenia, perspektywy, red. J.M. Fiszer, Warszawa 2012.

Bryła E., Czy mamy szanse na chinski węzet?, „Gazeta Wyborcza” 2017, 15 IX.

Brzeziński Z., Strategiczna wizja. Ameryka a kryzys globalnej potęgi, przeł. K. Skonieczny, Kraków 2013.

Chiny: będziemy wreszcie numerem 1. Rozmowa z prof. Bogdanem Góralczykiem, „Gazeta Wyborcza" 2017, $20 \mathrm{I}$.

Ciesielski M., Frankfurt może zostać największym beneficjentem Brexitu, Obserwatorfinansowy.pl, 31 VIII 2017, [online] https://www.obserwatorfinansowy.pl/tematyka/rynkifinansowe/frankfurt-moze-zostac-najwiekszym-beneficjentem-brexitu/.

Cooper R., Hard Power, Soft Power and the Goals of Diplomacy, [w:] American Power in the 21 $1^{\text {st }}$ Century, red. D. Held, M. Koenig-Archibugi, Cambridge-Malden 2004.

Czaputowicz J., Teorie stosunków międzynarodowych. Krytyka i systematyzacja, Warszawa 2007.

Czarnecki M., BREXIT niezgody, „Gazeta Wyborcz” 2017, 5 V.

Dadak K., Intermarium - plan B dla Polski po Brexicie?, „ARCANA” 2016, nr 4.

Deklaracja Rzymska, „Gazeta Wyborcza” 2017, 27 III.

EU-China 2020 Strategic Agenda for Cooperation, European External Action Service, [online] http://eeas.europa.eu/archives/docs/china/docs/eu-china_2020_strategic_agenda_en.pdf.

Ferguson N., Colossus. The Price of America's Empire, New York 2004.

Finkelstein L.S., What Is Global Governance, „Global Governance” 1995, nr 1.

Fiszer J.M., Czy Rosja pod rzadami Wtadimira Putina zagraża Europie i światu?, „Biuletyn Analiz i Opinii” 2015, nr 3.

Fiszer J.M., Polityka RFN wobec Rosji - szanse i zagrożenia dla Europy i świata w XXI wieku, „Rocznik Polsko-Niemiecki” 2017, nr 25, z. 1.

Fiszer J.M., Zadania i cele polityki zagranicznej Wtadimira Putina, „Myśl Ekonomiczna i Polityczna” 2016, nr 1.

Friederichs H., Der Stärkste steigt aus, „Zeit Online” 2016, 1 VIII, [online] http://www.zeit. de/politik/2016-08/grossbritannien-sicherheitspolitik-brexit-eu/komplettansicht, 10 III 2017.

Fuksiewicz A., Przysztość Unii Europejskiej - przegląd propozycji, Instytut Spraw Publicznych, Warszawa 2016.

Godement F., Czego chca Chiny?, przeł. K. Sarek, Warszawa 2016.

Godement F., Vasselier A., China at the Gates. A New Power Audit of EU-China Relations, European Council on Foreign Relations, London, XII 2017. 
Godlewski A., Co Niemcy straca, a co zyskaja na Brexicie, Obserwatorfinansowy.pl, 5 VII 2016, [online] https://www.obserwatorfinansowy.pl/tematyka/makroekonomia/co-niemcystraca-a-co-zyskaja-na-brexicie/.

Godlewski A., Niemcy mają dość sankcji wobec Rosji, Obserwatorfinansowy.pl, 22 IX 2017, [online] https://www.obserwatorfinansowy.pl/tematyka/makroekonomia/niemcy-majadosc-sankcji-wobec-rosji/.

Grosse T.G., Kryzys po Brexicie, „Rzeczpospolita” 2016, 15 VII.

Góralczyk B., Po 60 latach integracji Europie zabrakto spoiwa, Obserwatorfinansowy.pl, 25 III 2017, s. 1-6, [online] https://www.obserwatorfinansowy.pl/tematyka/makroekonomia/ po-60-latach-integracji-europie-zabraklo-spoiwa/.

Haliżak H., Międzynarodowa strategia geoekonomiczna Chin - perspektywa neoliberalnego instytucjonalizmu i kulturowo-cywilizacyjnej tradycji, „Myśl Ekonomiczna i Polityczna” 2017, nr 2.

Jarkowiec M., Do zobaczenia, panie prezydencie, „Gazeta Wyborcza” 2017, 14-15 I.

Jian Xu, Wspólnie budując Jedwabny Szlak XXI wieku promujemy i zacieśniamy przyjaźń, [w:] Chiny i świat zewnętrzny, red. J. Marszałek-Kawa, Torun 2016.

Kaczorowska M., Krajobraz polityczny po Brexicie, „Sprawy Międzynarodowe”2016, nr 3.

Keohane R.O., Nye J.S., Power and Interdependence. World Politics in Transition, Boston-Toronto 1977.

Kokot M., Jak Kreml na nowo podbija Europe metodami KGB, „Gazeta Wyborcza” 2017, 13 I.

Kokot M., Niemcy chca tylko Merkel na kanclerskim tronie, „Gazeta Wyborcza” 2017, 22 IX.

Kokot M., Wieliński B.T., Niemiecka gra w kolory, „Gazeta Wyborcza” 2017, 25 IX.

Koralewski J., Rozpad ZSRR a powstanie Federacji Rosyjskiej. Mocarstwowość utracona?, [w:] Mocarstwowość na przetomie XX i XXI wieku. Teorie, analizy, prognozy, red. S. Wojciechowski, M. Tomczak, Poznań 2010.

Kryzys 2008 a pozycja międzynarodowa Zachodu, red. R. Kuźniar, Warszawa 2011.

Krzemiński A., Do tanga trzeba trojga, „Polityka” 2018, nr 3.

Leonard M., L'Europe qui Protége. Conceiving the Next European Union, European Council on Foreign Relations, VIII 2017, [online] http://www.ecfr.eu/publications/summary/ leurope_qui_protege_conceiving_the_next_european_union.

Łastawski K., Od idei do integracji europejskiej, Warszawa 2003.

Macierewicz P., Indie stawiaja na globalizację i OZE, „Gazeta Wyborcza” 2018, 24 I.

Marmurek J., Dat nam przyktad Macron, jak zwyciezać mamy, „Gazeta Wyborcza” 2017, 12 V.

Ministerstwo Spraw Zagranicznych, Priorytety polskiej polityki zagranicznej 2012-2016, Warszawa 2012.

Möller A., Aydintasbas A., Dullien S., Liik K., Germany Votes: European Dilemmas in the Federal Election, European Council on Foreign Relations, Policy Brief, V 2017.

Ondarza N. von, Die verlorene Wette. Entstehung und Verlauf des britischen EU-Referendums, „Aus Politik und Zeitgeschichte” 2016, nr 49-50.

Ostrowski M., Amerykanin w Paryżu, „Polityka” 2017, 21-27 VI.

Pastusiak L., Prezydent dobrych intencji. Polityka zagraniczna Baracka Obamy, Warszawa 2015.

Piskorska B., Soft power w polityce UE wobec państw Partnerstwa Wschodniego, Lublin 2017. 
Podstawy prawne Unii Europejskiej. Traktat z Lizbony, Traktat o Unii Europejskiej, Traktat o funkcjonowaniu Unii Europejskiej wraz z protokotami i deklaracjami, Karta Praw Podstawowych, wprow., wybór i oprac. J. Barcz, Warszawa 2010.

President Jean-Claude Juncker's State of the Union Address 2017, European Commission, 13 IX 2017, [online] http://europa.eu/rapid/press-release_SPEECH-17-3165_en.htm.

Schulz M., Skrępowany olbrzym. Ostatnia szansa Europy, przeł. R. Formuszewicz, Warszawa 2014. Shapiro J., Pardijs D., The Transatlantic Meaning of Donald Trump: A US-EU Power Audit, European Council on Foreign Relations, 25 IX 2017, [online] http://www.ecfr.eu/publications/ summary/the_transatlantic_meaning_of_donald_trump_a_us_eu_power_audit7229.

Skrzypek A.A., Kryzys Unii, idei, polityki?, „Politeja” 2016, nr 43, [online] http://dx.doi. org/10.12797/Politeja.13.2016.43.01.

Smith J., Europa und das Vereinigte Königreich. Kleine Geschichte der Beziehungen seit 1945, "Aus Politik und Zeitgeschichte” 2016, nr 49-50.

Smith R., Przydatność sity militarnej. Sztuka wojenna we wspótczesnym świecie, przeł. A. i J. Maziarscy, Warszawa 2010.

Stiglitz J., Lekcja angielskiego, Obserwatorfinansowy.pl, 18 VII 2016, [online] www.obserwatorfinansowy.pl/tematyka/makroekonomia/lekcja.

Stodolak S., Europejska gospodarka dusi się $w$ politycznym pacie, Obserwatorfinansowy.pl, 25 IV 2017, [online] https://www.obserwatorfinansowy.pl/tematyka/makroekonomia/ europejska-gospodarka-dusi-sie-w-politycznym-pacie/.

Sturm R., Uneiniges Königreich? Großbritannien nach dem Brexit-Votum, „Aus Politik und Zeitgeschichte" 2016, nr 49-50.

Szubert K., Unia Europejska „dwóch prędkości”? Niemcy i WPBiO po Brexicie, „Biuletyn Instytutu Zachodniego" 2016, nr 281.

Świętek H., Wojna z Irakiem w 2003 roku. Gtówne przyczyny, Warszawa 2011.

Tajani A., Wielka Brytania wcią̇ może zmienić zdanie, Rp.pl, 29 III 2017, [online] http:// www.rp.pl/Unia-Europejska/170328856-Antonio-Tajani-Wielka-Brytania-wciaz-moze-zmienic-zdanie.html\#ap-1.

Theresa May to Seek General Election on 8 June, BBC.com, 18 IV 2017, [online] http://www. bbc.com/news/uk-politics-39629603.

Traktat z Lizbony, zmieniajacy Traktat o Unii Europejskiej i Traktat ustanawiający Wspólnotę Europejska, podpisany w Lizbonie 13 grudnia 2007 r. (teksty skonsolidowane), Dz.U. UE 2010, C 83.

Two Years until the 2019 European Election. Special Eurobarometr of the European Parliament, European Parliamentary Research Service, IV 2017.

Warszawski D., Nadchodzi czas Trumpów, „Gazeta Wyborcza”, 30 XII 2017-1 I 2018.

Węc J.J., Traktat lizboński. Polityczne aspekty reformy ustrojowej Unii Europejskiej w latach 2007-2009, Kraków 2011.

Wieliński B.T., Angela Merkel staje w szranki z Martinem Schulzem, „Gazeta Wyborcza” 2017, 4 IX.

Wieliński B.T., Czy Niemcy sa skazani na wielka koalicje?, „Gazeta Wyborcza” 2017, 20 IX.

Wieliński B.T., Najbrutalniejsza kampania od czasu zjednoczenia Niemiec, „Gazeta Wyborcza” 2017, 22 IX. 
Wieliński B.T., Wielka Rzesza w Bundestagu, „Gazeta Wyborcza” 2017, 16-17 IX.

Wieliński B.T., Kokot M., Kanclerz Merkel po raz czwarty, „Gazeta Wyborcza” 2017, 25 IX.

Zarychta S., Doktryny i strategie NATO 1949-2013, Warszawa 2014.

Zielonka J., Koniec Unii Europejskiej?, Polski Instytut Spraw Międzynarodowych, Warszawa 2014.

Prof. zw. dr hab. Józef M. FISZER, historyk, politolog, niemcoznawca. Kierownik Zakładu Europeistyki w Instytucie Studiów Politycznych PAN i Katedry Międzynarodowych Stosunków Politycznych Uczelni Łazarskiego w Warszawie. Wiceprzewodniczący Komitetu Nauk Politycznych PAN. Członek Polskiego Towarzystwa Studiów Europejskich. Redaktor naczelny kwartalnika „Myśl Ekonomiczna i Polityczna”. Członek wielu rad naukowych i redakcyjnych w kraju i za granicą. 